\title{
PALEONTOLOGY AND STRATIGRAPHY OF THE UPPER TRIASSIC KAMISHAK FORMATION IN THE PUALE BAY-CAPE KEKURNOI-ALINCHAK BAY AREA, KARLUK C-4 AND C-5 QUADRANGLE, ALASKA PENINSULA
}

by

Robert B. Blodgett ${ }^{1}$

\begin{abstract}
This report summarizes the paleontological character and stratigraphy of the Kamishak Formation in the Puale Bay-Cape Kekurnoi-Alinchak Bay area, Karluk C-4 and C-5 quadrangle, Alaska Peninsula. This 799.5-m- (2,625-ft-) thick strata succession has long been of interest to petroleum explorationists and has been considered to be the most likely source of the hydrocarbons found in oil and gas seeps in the greater Becharof Lake region. Paleontological data presented here are derived from published literature, unpublished internal paleontological reports of the U.S. Geological Survey, and new collections made by the author during the course of fieldwork conducted by the Alaska Division of Geological \& Geophysical Surveys (DGGS) in August 2007. Data are presented on various megafaunal groups found in this unit as well as for a single conodont element (conodonts have previously been unreported from Kamishak exposures on the Alaska Peninsula and lower Cook Inlet region). Biodiversity is highest in the lowermost biostromal limestone and overlying nodular limestone beds (each assigned to separate informal members here) limited in exposure to the headland area near the eastern entrance into Puale Bay, where a diverse fauna of bivalves, brachiopods, gastropods, scleractinian corals, and nautiloids is noted. To the northeast along the shoreline between this headland and Cape Kekurnoi, these lowermost beds are laterally replaced by deeper-water limestone and shale (referred to in this report as the limestone and shale member), which are characterized by an abundance of monotid bivalves (most of which belong to the species Monotis [Pacimonotis] subcircularis Gabb) and hydrozoan genus Heterastridium. The limestone and shale member also directly overlies the biostromal limestone and nodular limestone members at the headland and form the greater thickness of exposed Kamishak Formation strata. The Kamishak Formation appears to represent a single upward-deepening succession of late Norian age rocks that rest with an angular unconformity on Permian agglomerate, volcaniclastic rocks (sandstone), and limestone. The precise nature of the contact with the overlying, more clastic-rich Lower Jurassic beds, referred to earlier as the Bidarka Formation by Kellum (1945) or later by others as the Talkeetna Formation, is not yet well defined. Paleobiogeographic affinities of the various faunal elements found in the Kamishak indicate that the Peninsular terrane was probably situated in a tropical to subtropical setting during the Late Triassic and had close faunal ties with the Chulitna, Alexander, and Farewell terranes of southern Alaska, but apparently was separated by a significant distance from the Wrangellia terrane, which was also situated at a warm, low-latitude position during Late Triassic time.
\end{abstract}

\section{INTRODUCTION}

This paper summarizes the complete published record and some unpublished data regarding Upper Triassic fossils from the peninsula bounded by Puale Bay (formerly known as Cold Bay) and Alinchak Bay (figs. 1-3). These rocks have recently been referred to the Kamishak Formation (Detterman and others, 1996), a formation previously established to the north at Kamishak Bay near the upper end of the Alaska Peninsula. The outcrops discussed here are significant in that they represent the only Upper Triassic strata exposed east of the Bruin Bay fault on the Alaska Peninsula. In addition, these rocks have attracted much interest from petroleum explorationists as they have long been considered the

source of most of the potential extractable hydrocarbon resources in the Puale Bay-Becharof Lake-Wide Bay region (Hanna and others, 1937; Molenaar, 1995; Sralla and Blodgett, 2007; Blodgett and Sralla, 2008). The fossils discussed here are derived from a number of sources: Internal unpublished USGS fossil reports (often referred to as E\&R reports) that are mostly summarized in the Alaska Paleontological Database website (http://www.alaskafossil.org), published literature, and newly acquired megafossil collections made by the author during the four days of fieldwork conducted with DGGS August 12-15, 2007. Nearly all known fossils from the Kamishak Formation in the study area are listed

${ }^{1}$ U.S. Geological Survey, Contractor, 4200 University Dr., Anchorage, Alaska 99508 
in the Appendix. The only collections not listed are from private industry sources or reports, which I have not yet received permission to publish.

Upper Triassic (Norian) rocks, referred now to the Kamishak Formation (notably represented by limestone), are widely developed across much of the Peninsular terrane. References to their occurrence can be found in Capps (1923), Detterman and Hartsock (1966), Det-

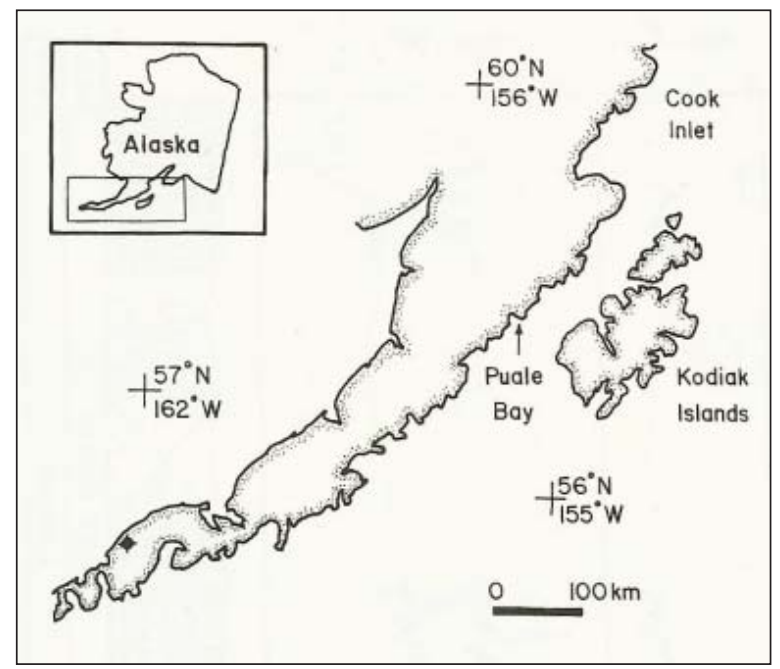

Figure 1. Index map showing location of Puale Bay on the Alaska Peninsula (from Wang and others, 1988). terman and Reed (1980), Detterman and others (1996), Kelley (1980), Martin (1915, 1916, 1921, 1926), Martin and Katz (1912), Newton (1983a, b, 1990), Smith (1925, 1926), Smith and Baker (1924), Stanley (1979), Stanton and Martin (1905), Wang (1987), and Wang and others (1988). The name Kamishak Formation (originally proposed as Kamishak Chert by Martin and Katz [1912] and subsequently changed to Kamishak Formation by Kellum [1945]) is now applied to nearly all exposures of Late Triassic age carbonates on the Alaska Peninsula and in the lower Cook Inlet region. It should be noted that outcrops of the Kamishak Formation occur on both sides of the Bruin Bay fault. Those exposures on its west side (that is, Kamishak Bay) belong to the Iliamna subterrane (name proposed by Wilson and others, 1985), where they are structurally complex and overmature in terms of oil and gas potential. Those included in the Chignik subterrane (also proposed by Wilson and others, 1985) on the east side of the Bruin Bay fault (Puale Bay) are only weakly to moderately folded and are well within the thermal range of oil and gas generation. Other Upper Triassic exposures in the Chignik subterrane can be found in the Port Graham area on the southern end of the Kenai Peninsula, on Ushagat Island (the largest of the Barren Islands), and along the northwestern coast of Kodiak Island. A lack of detailed study has left the latter named exposures poorly known, and strongly deserving of further investigation.

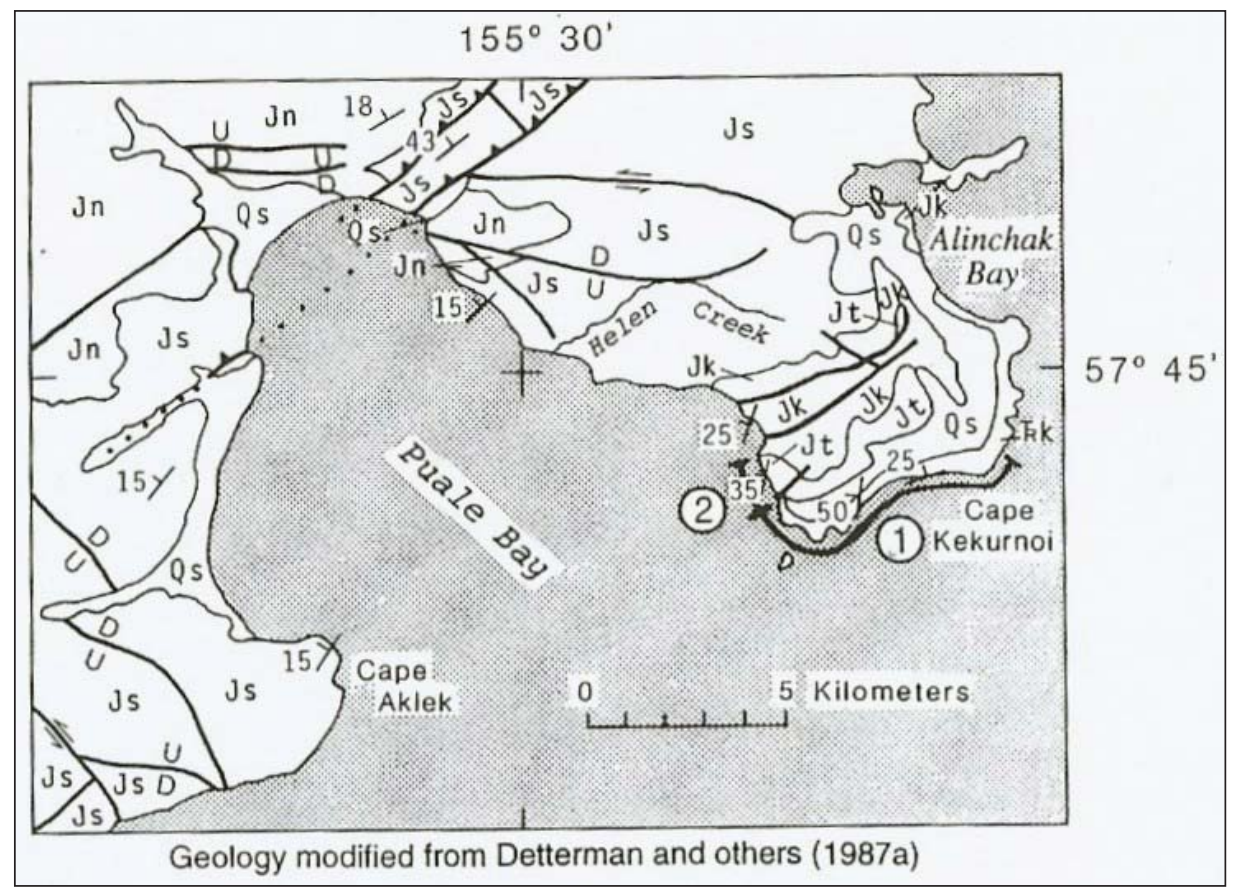

Figure 2. Distribution of the Kamishak Formation (TrK unit) according to Detterman and others (1996). Map shows location of their measured section (Section 1) in this unit (figure from Detterman and others, 1996, fig. 6B). 


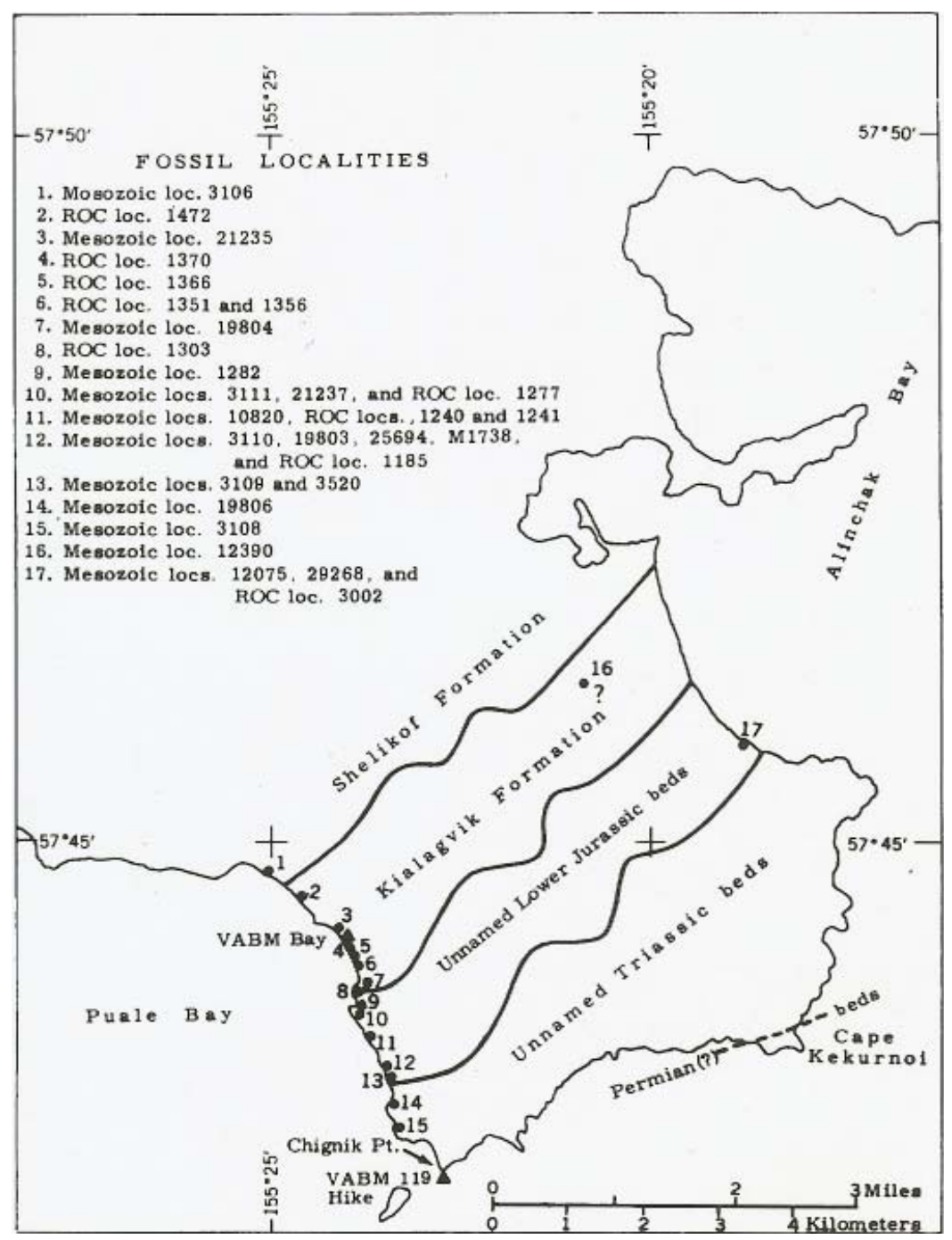

Figure 3. Distribution of unnamed Triassic beds (now referred to Kamishak Formation) according to Imlay and Detterman (1977). This figure more accurately reflects the distribution of Upper Triassic strata than that shown in figure 2. Note the presence of Permian(?) beds shown at Cape Kekurnoi, which were recognized by Hanson (1957).

\section{PREVIOUS WORK}

Alphonse Louis Pinart (a 19 ${ }^{\text {th }}$-century French ethnologist) visited the Alaska Peninsula in 1871 and was the first person to note the presence of Upper Triassic strata in the Puale Bay-Cape Kekurnoi-Alinchak Bay area (he referred to Puale Bay as “Nounakalkhak”) (Pinart, 1873). He collected monotid bivalves that were described in two papers (the latter with illustrations) by Fischer (1872, 1875), who identified them as belonging to the species Monotis salinaria Bronn. These specimens generated considerable interest for their then very remote geographic nature, and were referred to by Teller (1886), who suggested they represent a species of Pseudomonotis related to Pseudomonotis ochotica (Keyserling) ( $P$. ochotica is now referred to the genus Monotis). Mojsisovics (1886) believed this locality represented an occurrence of what he called his "Arctic Pacific Trias province.” Frech (1908) reexamined Pinart's specimens and identified them as including both the typical form of Pseudomonotis ochotica (Keyserling) and also Pseudomonotis ochotica var. sparicostata Teller, the latter taxon being figured. Stanton and Martin (1905, p. 394, 396) make only passing reference to the presence of Upper Triassic strata at Cold (now Puale) Bay, stating that the fauna is "almost limited to the single species Pseudomonotis subcircularis Gabb” but noted that subsequent large collections made from the region indicated that the forms earlier described and illustrated by Fischer as Monotis salinaria should rightfully belong to Gabb's species.

Martin (1916, p. 699-700) makes only a brief comment on the Puale Bay exposures, stating that they consist of limestone and shale, $700 \mathrm{ft}$ (213 m) or more in thickness, and contain Pseudomonotis subcircularis (Gabb) (illustrated on pl. 29, fig. 1 of his publication and reproduced here in fig. 9). He also noted that the beds bearing the monotid bivalves were underlain by contorted cherts, underlain in turn by basic igneous rocks. Martin (1921, p. 57-58) gives a slightly more detailed description of the unnamed Triassic succession 
between Cold (Puale) and Alinchak bays, and noted that at Alinchak Bay contorted cherts (bearing no fossils) underlie limestone and shale containing monotids, and that the cherts are underlain by basic igneous rocks. It is interesting that no subsequent investigations have documented the presence of cherts in this part of the section. The igneous rocks that Martin refers to appear to be part of the volcaniclastic unit that was recognized at Cape Kekurnoi by Hanson (1957) and thought to possibly be part of a Permian-age basement complex. In addition, Martin (1921, p. 58-59) recognized a change upward from calcareous beds beneath into less calcareous beds as one moves from the Upper Triassic into the Lower Jurassic. No definite horizon could be identified by Martin as the Triassic-Jurassic boundary as this appears to occur in a gradual transition in which no fossils were recovered. Capps (1923) made a detailed description of the Upper Triassic beds between Puale Bay and Alinchak Bay. He referred to them as an unnamed unit of "dense thin-bedded limestone and shale" of Late Triassic age (Capps, 1923, pl. II). He estimated the thickness as well over 1,000 ft (305 m), consisting of "hard dense thin-bedded limestone and limy shale, cut by dikes and sills of basalt” (Capps, 1923, p. 92). He also noted that many of the limestone beds were dominated exclusively by a single form of Pseudomonotis (now recognized as Monotis [Pacimonotis] subcircularis Gabb) and the transition into the overlying Jurassic beds was not represented by a structural break, there being "apparently perfect conformity between the Triassic and Jurassic beds” (Capps, 1923, p. 93). Capps regarded the top of the Upper Triassic to "end at the point where the sandy phase begins to appear” (Capps, 1923, p. 93). The Upper Triassic beds were referred to by Smith (1926, p. 65) simply as "massive and thin-bedded limestone of Upper Triassic age" that were overlain conformably by Lower Jurassic limestone, sandstone, and shale. His 1926 paper incorporated his fieldwork conducted in 1924, which updated earlier U.S. Geological Survey mapping done by him, A.A. Baker, and S.R. Capps. In this paper, the lowest beds of the Upper Triassic as exposed at Cold (Puale) Bay were now shown to consist of massive buffcolored limestone $85 \mathrm{ft}(26 \mathrm{~m})$ in thickness, overlain by blue nodular limestone $40 \mathrm{ft}(12 \mathrm{~m})$ in thickness (according to fig. 2 of Smith, 1926, but $30 \mathrm{ft}[9 \mathrm{~m}]$ in text on p. $66)$, overlain in turn by a thicker thin-bedded limestone succession that included a 100-ft- (30-m-) thick interval of basalt (Smith, 1926, fig. 2, shown here as fig. 4). The thin-bedded succession containing Pseudomonotis (now recognized as Monotis) was indicated to be slightly more than $700 \mathrm{ft}(>213 \mathrm{~m}$ ) in thickness (Smith, 1926, p. 69). The Triassic-Jurassic boundary was not determined, but indicated to be within the upper part of Smith's thin-bedded limestone. A total thickness of $900 \mathrm{ft}(275 \mathrm{~m})$ was suggested for the Upper Triassic succession by Smith
(1926). Smith (1926, fig. 2) indicated that the lowest beds of the Upper Triassic consisted of thin-bedded limestone at Alinchak Bay (similar to our observations in 2007 west of Cape Kekurnoi).

The Upper Triassic succession in the study area was shown on the map of Moore (1967) as the Trvm (volcanic and marine sedimentary rocks) unit. On the geologic map of the same area (von Huene and others, 1979, pl. 2) the Upper Triassic was shown as the Trsv (sedimentary and volcanic rocks), with the exception of the rocks at the outermost end of Cape Kekurnoi, which were shown as being assigned to the unit with question. The exposures at Cape Kekurnoi, consisting of basalts, are here considered to be part of the underlying Paleozoic (Permian) basement complex as suggested by Hanson (1957).

Two 1:250,000-scale geologic maps were released by Detterman and others $(1983,1987)$, both of which left the Upper Triassic beds unnamed but represented by a single unit (Trlv) on the map of Detterman and others (1983) and two units (Trls and Trv) on the map of Detterman and others (1987). The Detterman and others (1987) map was the first one to apply the name Talkeetna Formation (a formation established by Martin [1926] for exposures in the southern Talkeetna Mountains) to the previously unnamed Jurassic rocks exposed between Puale and Alinchak bays (see Imlay and Detterman [1977] and Imlay [1981] for detailed faunal lists from the Lower Jurassic of the study area). The name Bidarka Formation was established earlier by Kellum (1945) for rocks he considered to be Early Jurassic in age that were exposed along the east side of Puale Bay. This raises the question of stratigraphic nomenclatorial priority, which needs to be addressed at some point in the future.

Wang (1987) presented the results of his M.S. thesis, emphasizing the sedimentology of the Upper Triassic strata in the study area. He recognized three major facies in his measured section ( 700 $\mathrm{m}[\sim 2,300 \mathrm{ft}]$ ) along the east side of Puale Bay: (1) a basal coralline biomicrite facies $45 \mathrm{~m}(148 \mathrm{~m})$ thick that contains abundant scleractinian corals, spongiomorphs, and terebratulid brachiopods (equivalent to the informal "biostromal member" used here); (2) a carbonate conglomerate facies (overlying the basal biomicrite facies) that is $25 \mathrm{~m}$ (82 ft) thick that contains corals, bivalves, ammonoids, nautiloids, and gastropods in cobble-sized lithoclasts (equivalent to the informal "nodular limestone member" used here); and (3) the uppermost and much thicker rhythmite facies, including calcareous/siliceous shale and siliceous limestone/chert that contains abundant monotid bivalves (equivalent to the informal "limestone and shale member" used here). Wang and others (1988) later presented essentially the same data in the GSA Bulletin. Newton (1990) studied the Triassic-Jurassic boundary section at Puale Bay. She recognized latest 


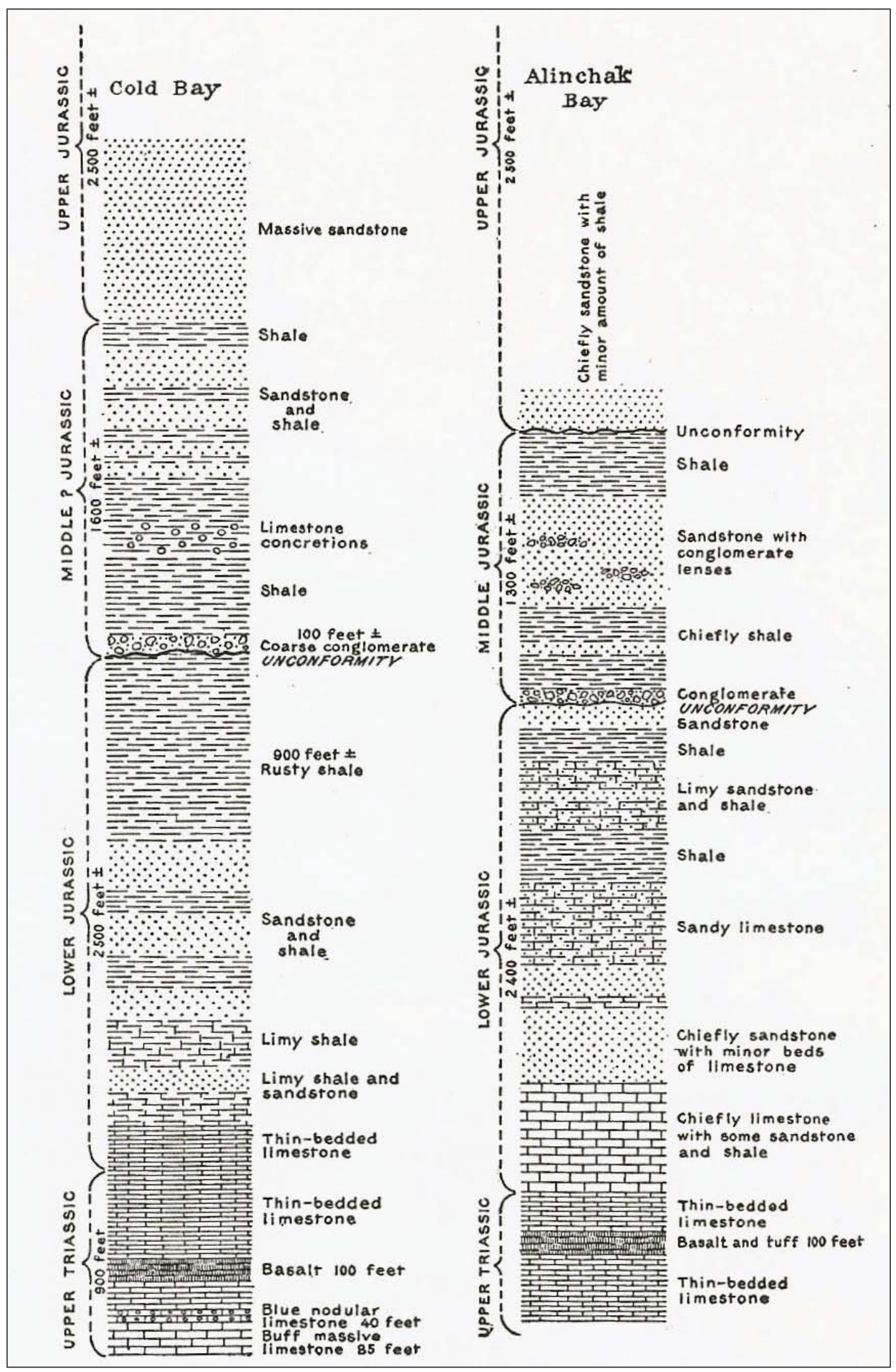

Figure 4. Columnar sections of Upper Triassic and Jurassic strata exposed at Cold (Puale) Bay (left column) and Alinchak Bay (right column) (from Smith, 1926, fig. 2). 
Norian and Hettangian intervals in the section, but noted that they were separated by an approximately 50-m- (164-ft-) thick barren interval (in terms of shelly fauna) containing high concentrations of the trace fossils Thalassinoides and Chondrites. She suggested that this interval included the Triassic-Jurassic boundary that was deposited under dysaerobic conditions.

Detterman and others (1996) were the first to apply the stratigraphic term Kamishak Formation to the previously unnamed Upper Triassic strata exposed in the study area (areal distribution of this unit is shown in fig. 2). They presented a measured section (part of their fig. 6; reproduced here as fig. 5) that comprised a total measured thickness of $799.5 \mathrm{~m}(2,623 \mathrm{ft})$. They also indicated a gradational contact with the overlying Lower Jurassic strata that they assigned to the Talkeetna Formation. They recognized 14 subunits within the Kamishak Formation, of which their lowermost subunit (no. 1) corresponds to the informal nodular limestone member used here.

Pálfy (1997) and Pálfy and others (1999) presented data primarily focused on the Lower Jurassic succession exposed on the east shore of Puale Bay, but differed from earlier investigators in suggesting that the Kamishak Formation extended into the Hettangian, with a boundary between the Kamishak Formation and overlying Talkeetna Formation situated higher in the section. Of interest is the fact that Pálfy and others (1999, fig. 2) showed the lowermost fossiliferous horizon in the Lower Jurassic (middle Hettangian in age) as separated by a normal fault from unfossiliferous, lithologically very similar, presumably uppermost Triassic strata. Barbacka and others (2006) illustrated and described plant macrofossils from middle Hettangian strata on the east shore of Puale Bay, which they assigned to the uppermost part of the Kamishak Formation.

Figure 5. Columnar section of the Kamishak Formation exposed in the Cape KekurnoiPuale Bay area according to Detterman and others (1996; section 1 of their fig. 6). They indicate a total thickness of $799.5 \mathrm{~m}$ (2,623 ft) for the Kamishak Formation.

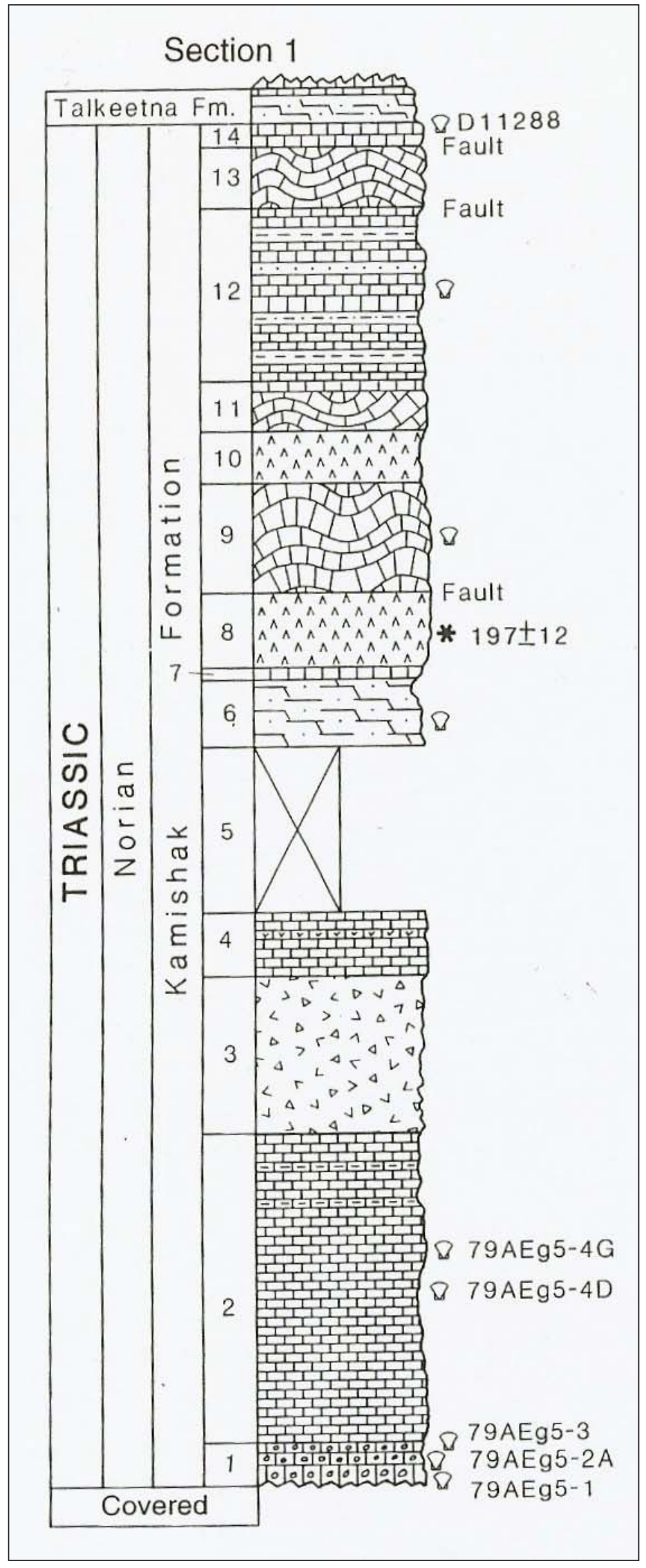




\section{REINTERPRETED STRATIGRAPHY}

The Upper Triassic strata of the study area have only recently been referred to the earlier-named Kamishak Formation by Detterman and others (1996). Only two modern investigators have attempted to illustrate a stratigraphic section of the formation: (1) Wang (1987) and Wang and others (1988), who indicated a total thickness of approximately $700 \mathrm{~m} \mathrm{(2,300} \mathrm{ft} \mathrm{);} \mathrm{and} \mathrm{(2)} \mathrm{Detterman}$ and others (1996), who indicated the thickness to be $799.5 \mathrm{~m}$ (2,623 ft). Neither investigation presented rigid lithostratigraphic evidence for determining the top and bottom of the formation. In neither paper was the base considered exposed onshore in the study area, although the authors suggested that older beds were present offshore on small islands, one of which consisted of limestone yielding mid-Permian fossils (Hanson, 1957; Jeffords, 1977). These islands form part of a pre-Mesozoic complex of volcaniclastic rocks, volcanic rocks, and limestone (the latter yielding Permian fossils). The base of the Kamishak Formation directly overlies volcaniclastic sands of this late Paleozoic complex along the shoreline of the mainland of the peninsula (fig. 6) west of Cape Kekurnoi. The contact is an angular unconformity with quite visible erosional truncation of the underlying volcaniclastic strata. The presence of a Permian unit on the peninsula was suggested earlier (with a questioned age, due to the absence of fossils) on the geologic map presented in Hanson (1957, fig. 1), who indicated the presence of Permian (?) agglomerate onshore. Unfortunately, previous and subsequent investigators missed this contact, perhaps because of the brevity of most fieldwork done in the region, as well as the concentration of study focused on the Upper Triassic exposures on the east side of Puale Bay, resulting in a lack of observations on the exposures near Cape Kekurnoi and Alinchak Bay.

Based on limited time on the Kamishak Formation in the study area, I believe three informal members can be designated that are easily recognizable by a field geologist. The first is the thick- to massive-bedded "biostromal limestone member" (only locally developed). It is equivalent to the basal coralline biomicrite facies of Wang (1987), a unit $45 \mathrm{~m}$ (148 ft) thick and containing abundant scleractinian corals, spongiomorphs, and terebratulid brachiopods. The next highest member, the "nodular limestone member" (again only locally developed), corresponds to the carbonate conglomer-

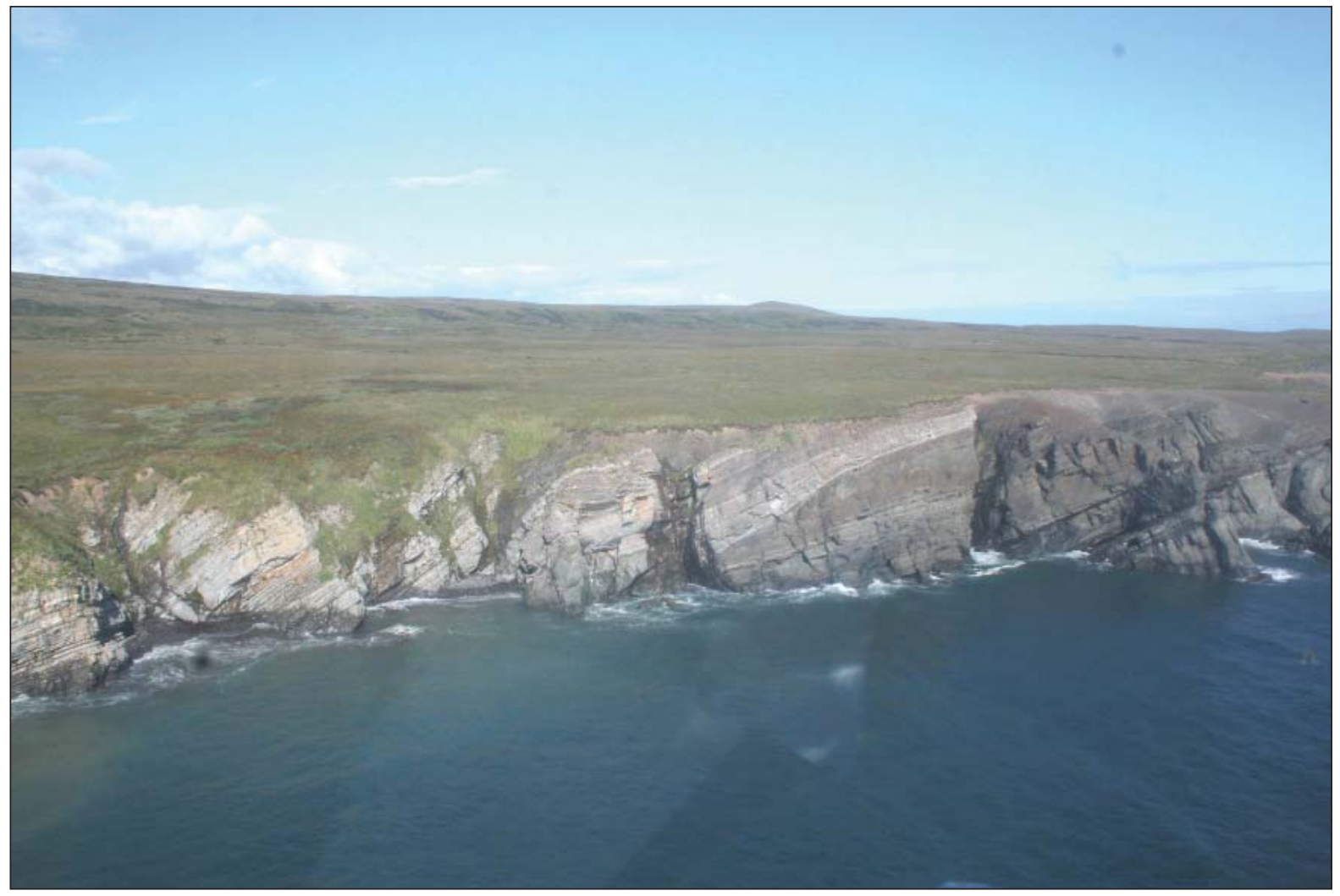

Figure 6. Aerial view of Upper Triassic carbonates of the Kamishak Formation (light-colored rocks) $0.5 \mathrm{mi}$ (0.8 km) west of Cape Kekurnoi, showing lower contact with underlying Permian volcanic agglomerate and volcaniclastic rocks (dark strata). Contact is an angular unconformity with strikingly obvious erosional cutoff of underlying bedded Permian rocks. Photo taken by Bryan Sralla (Fort Worth, TX). Same as figure 2 in Blodgett and Sralla (2008). 
ate facies of Wang (1987), a unit $25 \mathrm{~m}$ (82 ft) thick that contains corals, bivalves, ammonoids, nautiloids, and gastropods in cobble-sized lithoclasts. The highest member, the "limestone and shale member," equivalent to the rhythmite facies of Wang (1987), consists of thin- to medium-bedded calcareous shale, siliceous shale, limestone, and minor volcaniclastic beds. This unit forms the greater part of the formation and on the east of the outcrop belt, from $0.5 \mathrm{mi}(0.8 \mathrm{~km})$ west of Cape Kekurnoi to Alinchak Bay, it composes the entire formation, the lowermost two westerly developed members being absent.

The exposed base of the Kamishak Formation has until now been observed only along the shoreline approximately $0.5 \mathrm{mi}(0.8 \mathrm{~km})$ west of Cape Kekurnoi (fig. 6). Here, probable Permian-age volcaniclastic beds are overlain by thin-bedded limestones of the Kamishak Formation that bear local concentrations of the bivalve Monotis (Pacimonotis) subcircularis Gabb. Farther west, at the east side of the entrance into Puale Bay, the lowest beds of the Kamishak Formation are of somewhat differing character, including the basal, relatively massively bedded biostromal member, developed only near a small headland, which borders the east entrance to Puale Bay, and the overlying nodular limestone member, which likewise is limited to this headland (figs. 7-8). Overlying the nodular limestone member are typical beds of the lower part of the thin- to medium-bedded limestone and shale member of the Kamishak Formation. A rapid facies change appears to exist between the lowermost Kamishak Formation beds at the headland and those to the east near Cape Kekurnoi. No one has seemingly worked out this relationship, which would require careful traversing of shoreline and adjoining exposures between the two areas. Several possibilities readily come to mind: (1) The local development of the biostromal member and nodular limestone member may represent only a locally developed facies, laterally equivalent to the lower part of the limestone and shale member; or (2) the local development of the first two mentioned members may occur as initial fill of an extensively channeled surface, later being covered by deeper-water deposits that covered the entire region during a later rapid transgressive event.

The top of the formation remains to be rigorously defined lithostratigraphically. Both earlier and later workers have recognized that the Upper Triassic beds are gradational in character with those of the overlying Lower Jurassic. Calcareous sediments dominate the lower part of the interval, with a gradual increase of volcanicastic sediments higher in the section. Monospecific accumulations of monotid bivalves (represented primarily by two species of Monotis) typify much of this unit. No biostratigraphically-defined Triassic-Jurassic boundary has yet been identified. Most previous workers have suggested that the Late Triassic beds are part of the Kamishak Formation, while those of Early Jurassic age belong to a different unit. An exception, however, is the work of Pálfy (1997), Pálfy and others (1999), and Barbacka and others (2006) who believe the carbonaterich beds go up into the Hettangian, and assign them to the Kamishak Formation, recognizing the overlying Talkeetna Formation just above where the beds are dominated by non-calcareous clastic rocks.

Age control to date for the Kamishak Formation has relied almost entirely on megafossil invertebrates (primarily monotid bivalves). Conodonts have not yet been reported from the unit, and ammonoids have not been well documented from the formation. In terms of facies and succession of faunal types (communities), the Kamishak Formation appears to represent a transgressive, deepening-upward succession of beds primarily of late Norian age. No Rhaetian- (uppermost Triassic) age beds have been recognized from the succession, and the oldest dated Jurassic fauna is of middle Hettangian age (Imlay, 1981). A detailed study of the Triassic-Jurassic transition from this area would be an invaluable contribution to better understanding the tectonic evolution of the Peninsular terrane.

\section{PALEONTOLOGY}

Ammonoids-Ammonoids are not common in the Kamishak Formation exposures of the study area. In terms of modern taxonomic nomenclature, only four genera have been reported in the literature: Pinacoceras and Trachyceras? from beds probably correlative with the nodular limestone or biostromal members recognized in this report, and Halorites and Metasibirites from higher beds of the platy limestone and shale member.

Bivalves-Bivalves are by far the most common fossil group found in the Kamishak Formation exposures in the study area. Most notably to even the casual observer is the abundance of monotid bivalves throughout most of the Kamishak exposures here. As noted by Silberling and others (1997, p. 11):

"In wave-cut exposures along the shores of Puale and Alinchak Bays, on either side of Cape Kekurnoi, several hundred meters of Upper Triassic, well-bedded, dense limestone, shale and minor volcaniclastic rocks (the "bedded cherts" lithofacies of Wang and others, 1988) overlie platform-carbonates and volcanic rocks, all of which are late Norian in age. Monotis (P.) subcircularis is well represented in collections from relatively low in the well-bedded sequence, however, $\mathrm{M}$. (M.) alaskana occurs near its top. Although the section is disturbed by faults and folds, Detterman and others (1996) reported a minimum stratigraphic separation of about $75 \mathrm{~m}$ between these two species in an unbroken partial section in Alinchak Bay.” 


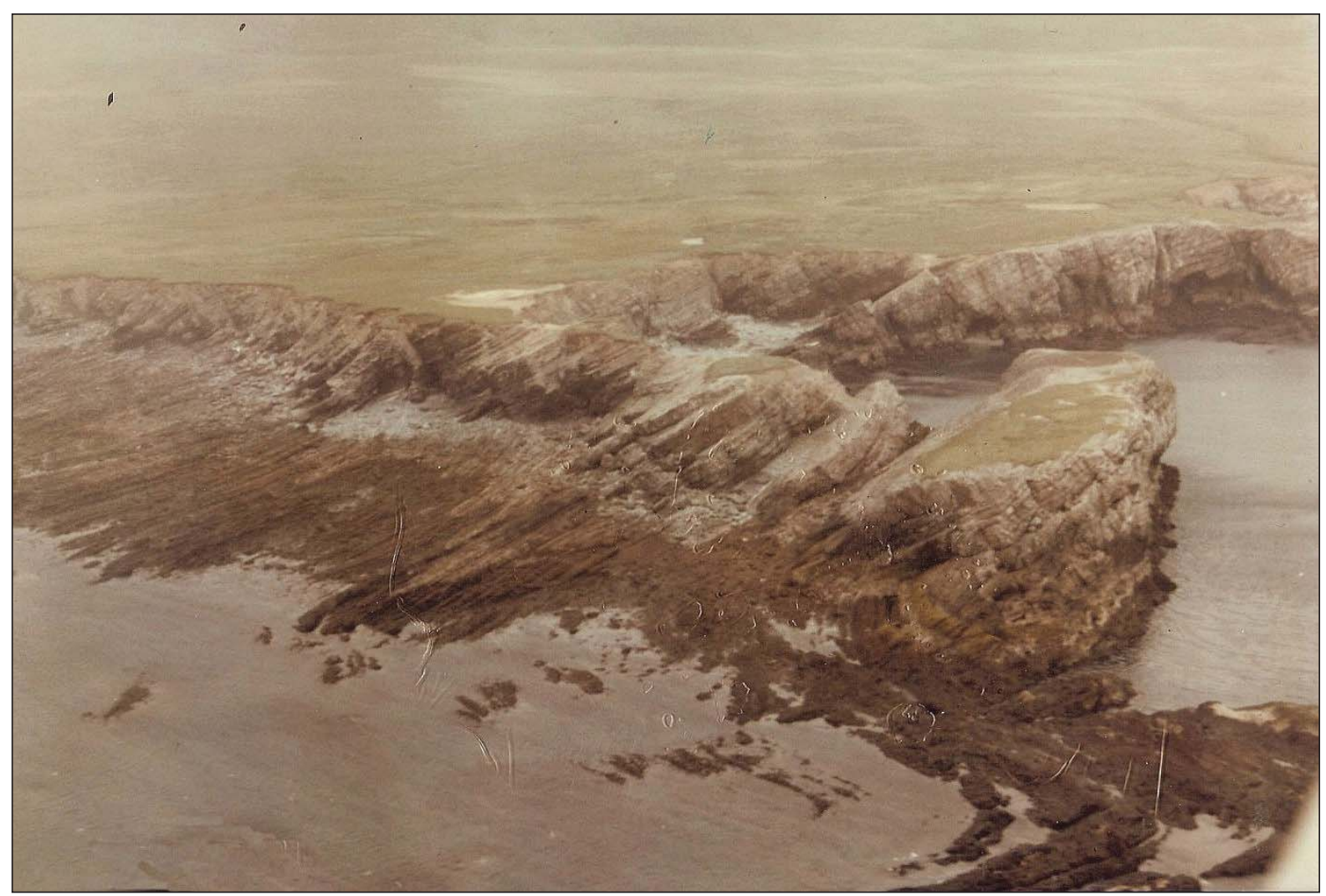

Figure 7. Aerial view of headland situated at the center of the lower margin of Sec. 33, T 28 S, R 37 W, Karluk C-4 and C-5 quadrangle. The prominent massif forming the outermost end of the headland comprises the primary (thickest-known) exposure of the biostromal member. Wang (1987) estimated a minimum thickness for this member at $45 \mathrm{~m}$ (148 ft). Outcrops farther inland (to the left) include the overlying nodular limestone and platy limestone and shale members. Photo, taken at an extremely low minus tide, courtesy of Les Magoon (USGS, Menlo Park, CA).

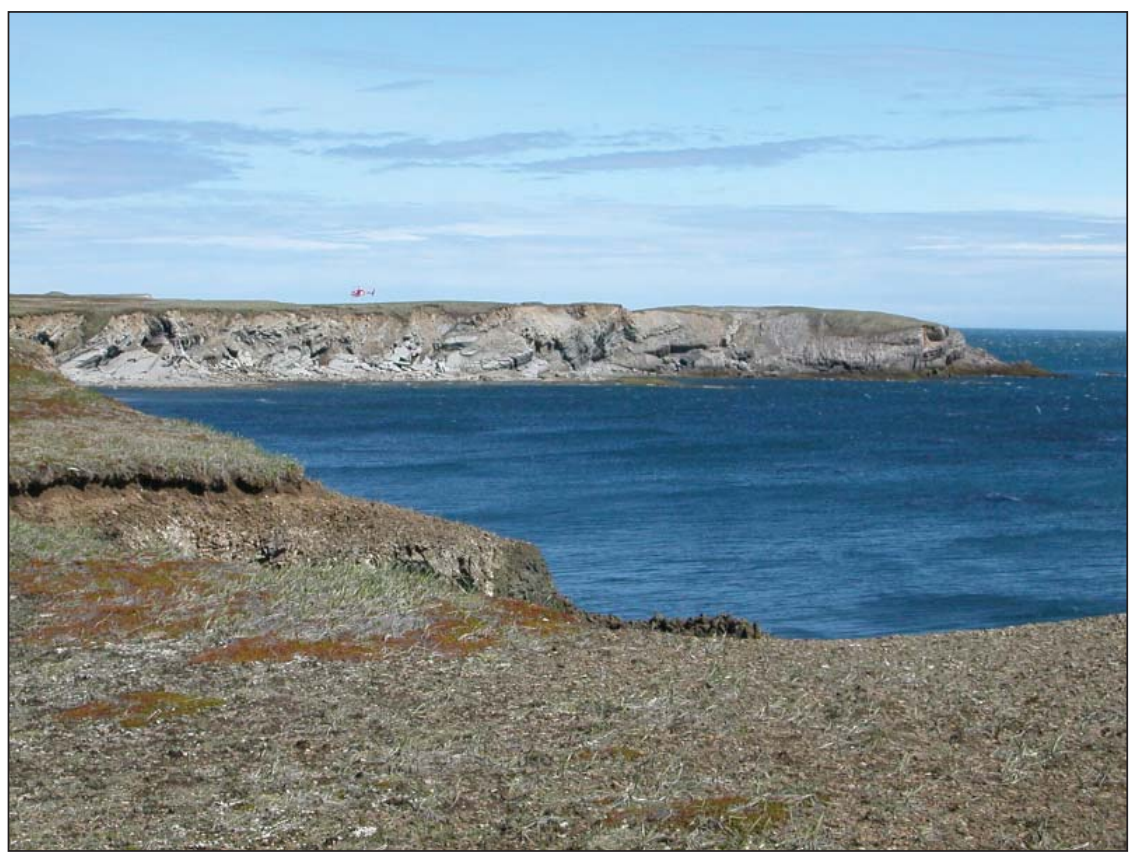

Figure 8. A different view showing the lower part of Kamishak Formation section on the east side of the same headland shown in figure 7. The more massively bedded biostromal and nodular limestone members exposed on the extreme right of the headland and the lower part of the platy limestone and shale member (note finer scale bedding) are exposed on the left side (helicopter for scale). 
Monotis (Pacimonotis) subcircularis Gabb (figs. 9-11) is by far the most abundant bivalve found in the Kamishak Formation, and the typical form that most field geologists have collected in the region. In addition to the two species M. (P.) subcircularis and M. (Monotis) alaskana that typify much of the limestone and shale member, a much rarer third species has been recognized by this author from the Standard Oil Co. of California collections that were donated to the California Academy of Sciences (CAS) in San Francisco. This species is identical to a form illustrated and identified as Monotis (Entomonotis) sp. cf. M. (E.) ochotica densistriata (Teller, 1886) by Silberling and others (1997). This form co-occurs with Monotis (Pacimonotis) subcircularis in the California Academy of Sciences collections.

The absence of any intermediate morphotypes indicates that we are observing two separate taxa. Several left valves of this form are illustrated in figures 12 and 13. This form has previously been recognized in the Alexander terrane of southeast Alaska, where it occurs at USGS Mesozoic locality 1912 on Kuiu Island.

The limestone and shale member is dominated by nearly monospecific accumulations of monotid bivalves. However, both the underlying biostromal and nodular limestone members appear to lack monotids, but rather contain a much more diverse assemblage of bivalves. Pinnid, myophorid, and pectenacid bivalves are most common. Genera previously reported from these lower two members include: Amusium, Cassianella (common in Norian bivalve assemblages elsewhere in southern Alaska), Minetrigonia, Myophoria, Ostrea?, Palaeopharus, Pinna, Pinnigena, Pleuromya, and “Trichites."
Oyster shells, mostly in the form of large fragments (identified in this study as "Ostrea" sp.) are common elements in the nodular limestone member (fig. 14). Oyster shells with somewhat similar laminar shell structure (?Lopha cordillerana) have been illustrated from Norian age strata of the Antomonio Formation of Sonora, Mexico, by McRoberts (1997, fig. 4). A detailed study of the bivalve fauna from the lower Kamishak Formation of the study area would be a fruitful area for future paleontological work in this part of Alaska.

Brachiopods-Brachiopods are common faunal elements in both the biostromal and nodular limestone members. The author knows of no occurrences of brachiopods in the limestone and shale member. Smooth terebratulids seem to be typical for both members (figs. 15-16), with only a few specimens of rhynchonellid or spiriferid brachiopods being noted to date.

The terebratulids are common enough to have formed a monotaxic accumulation of silicified valves in a Standard Oil Co. of California field collection now deposited in the California Academy of Sciences (CAS locality 29823). It would be highly beneficial to have a formal taxonomic study done on these brachiopods, and contact has been made with Dr. Michael R. Sandy (University of Dayton, Dayton, Ohio) to explore the possibility of a joint paper on this subject. Of note is the fact that one terebratulid brachiopod from the author's collection 07RB14 has preserved original color patterns, consisting of radial rays originating on the umbo (fig. 16). This is the first occurrence known by either Dr. Sandy or the author in which color patterns have been preserved in a Triassic brachiopod from North America.
Figure 9. Drawing (from Martin, 1916, pl. 29, fig. 1) showing right valve of Pseudomonotis subcircularis (Gabb) [now referred to Monotis (Pacimonotis) subcircularis Gabb] from USGS Mesozoic locality 3107.

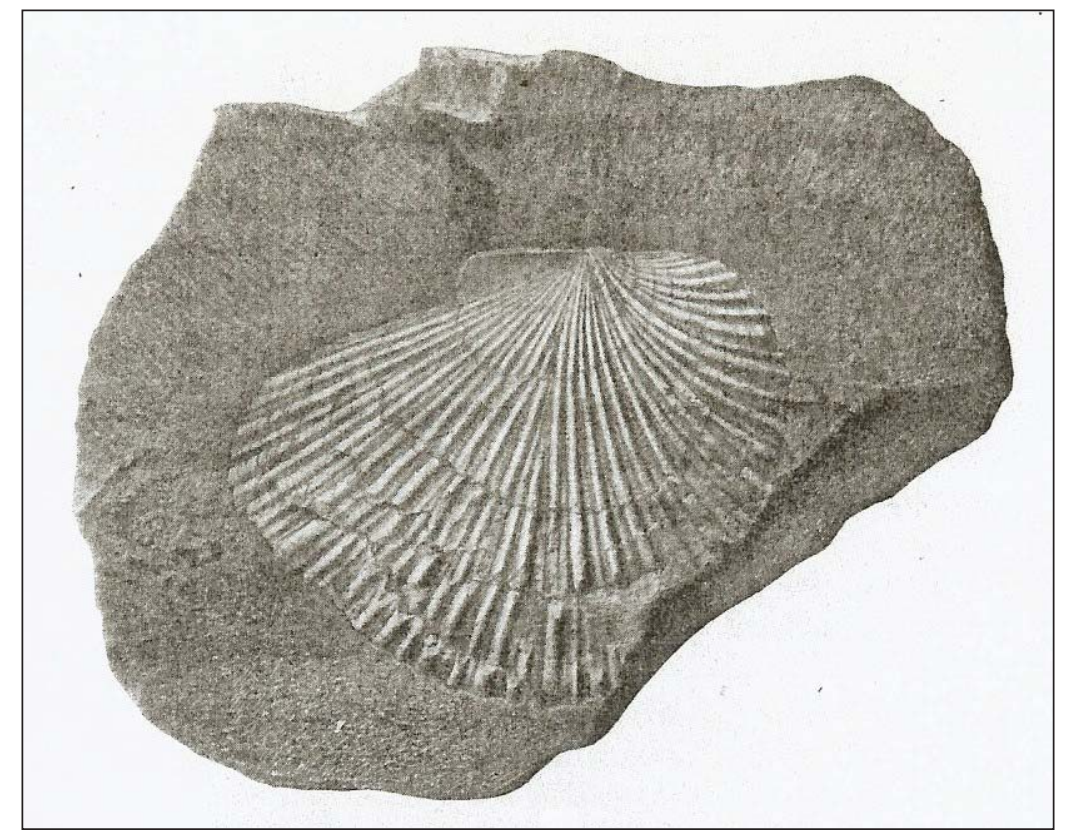




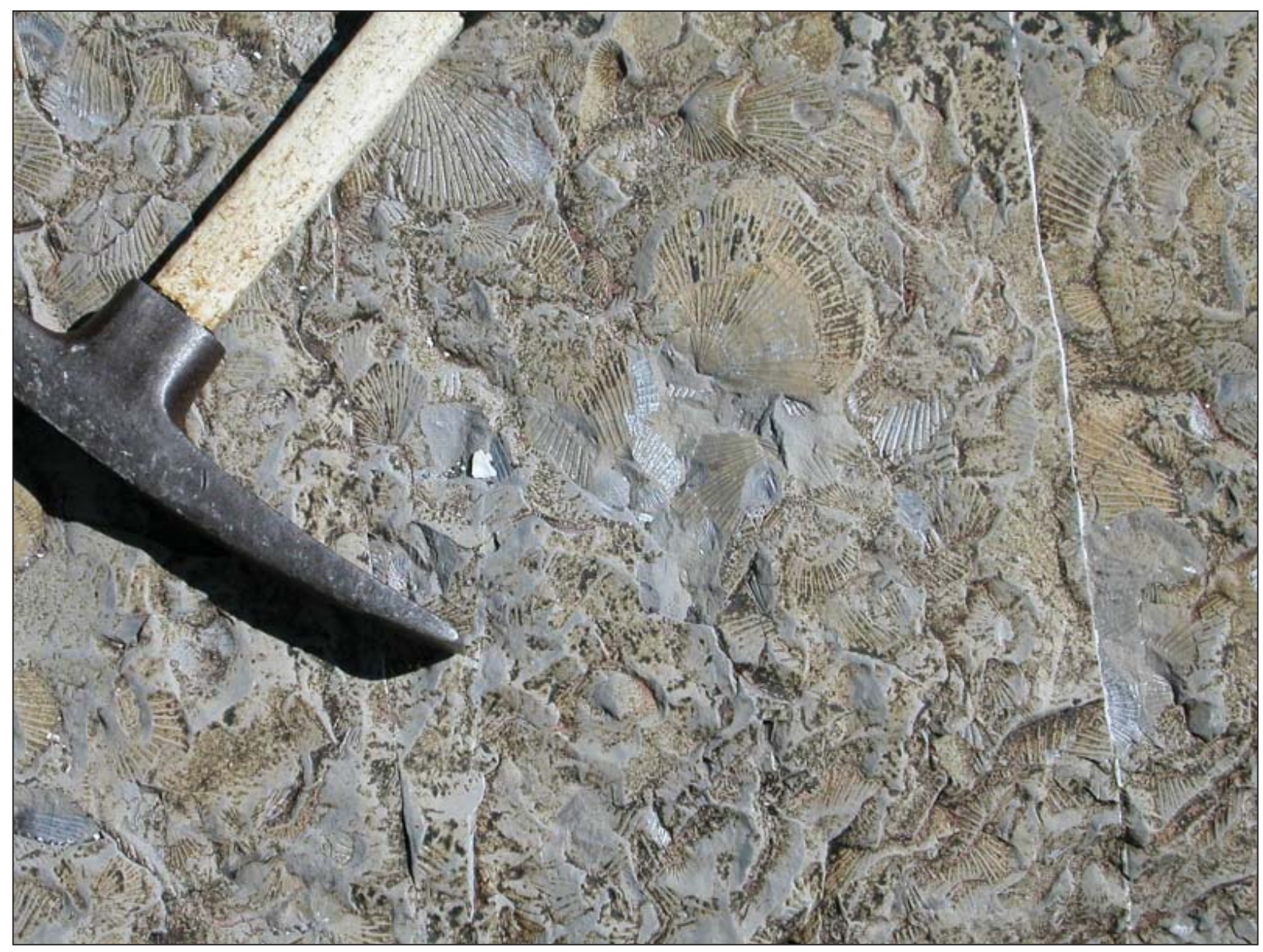

Figure 10. Bedding surface exposure showing typical abundant accumulation of Monotis (Pacimonotis) subcircularis Gabb on bedding plane in lower part of the platy limestone and shale member of the Kamishak Formation.

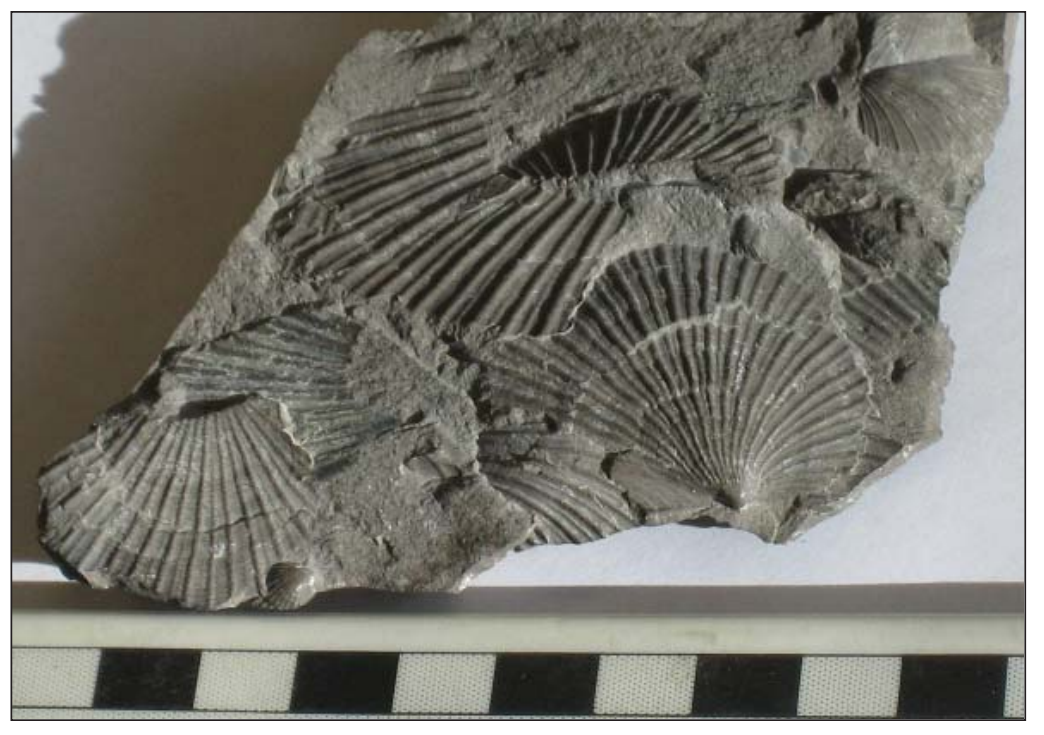

Figure 11. Slab bearing numerous specimens of Monotis (Pacimonotis) subcircularis Gabb. Limestone and shale member of the Kamishak Formation. California Academy of Sciences locality 29039. Scale marked in centimeters. 


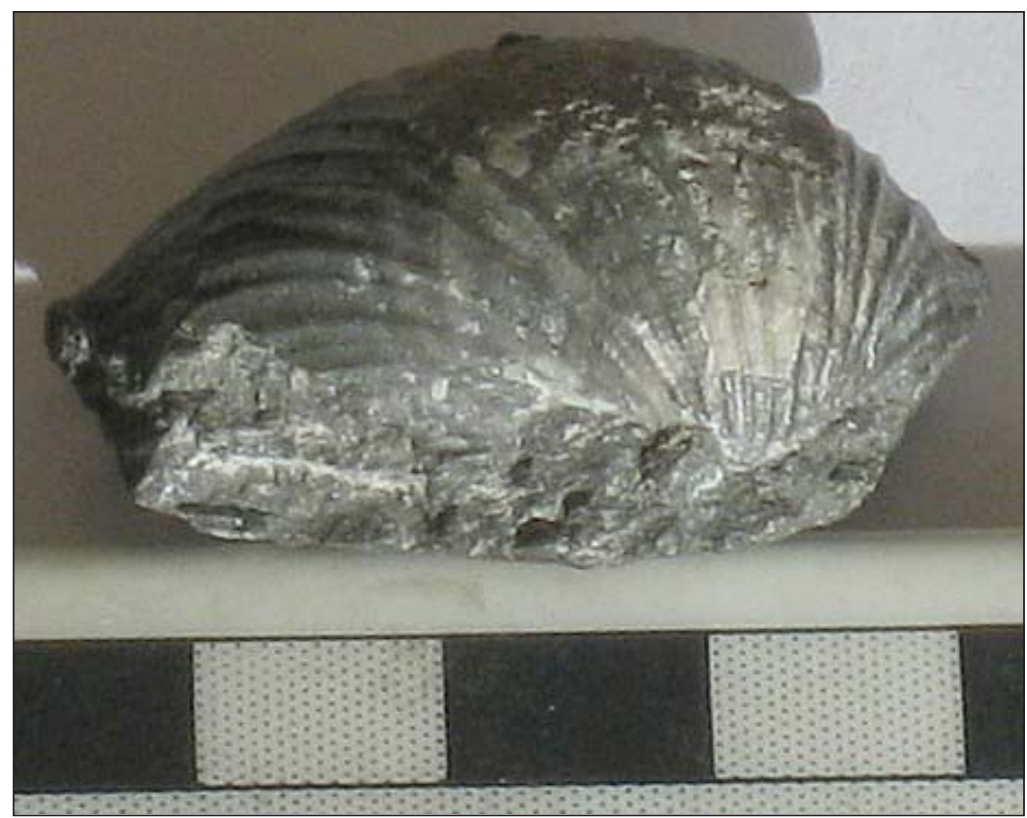

Figure 12. Left valve of Monotis (Entomonotis) sp. $c f$. M. (E.) ochotica densistriata (Teller, 1886) of Silberling and others (1997). Note highly convex nature of valve, which clearly distinguishes this subgenus. California Academy of Sciences locality 29823. Scale bar in centimeters.

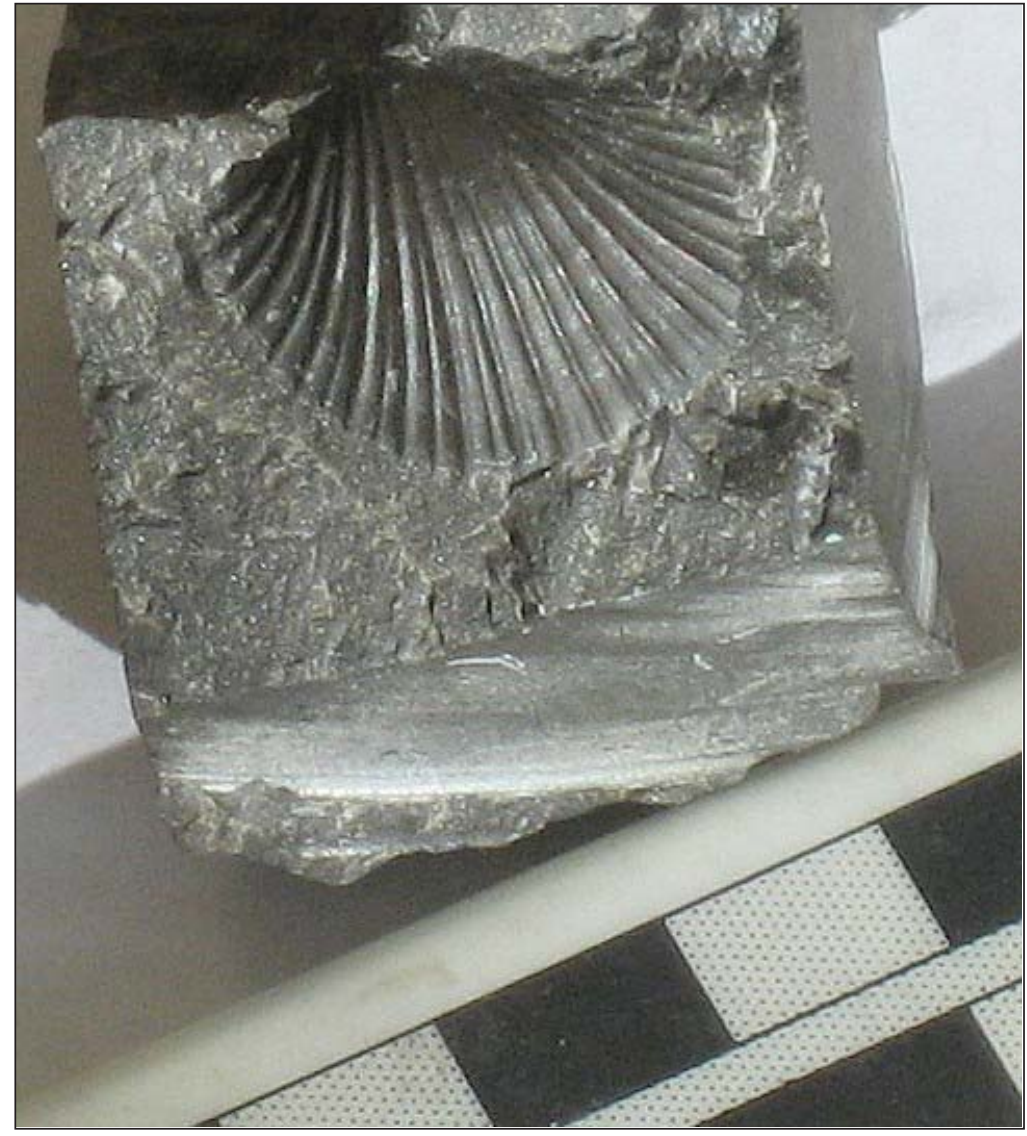

Figure 13. Left valve of Monotis (Entomonotis) sp. cf. M. (E.) ochotica densistriata (Teller, 1886) of Silberling and others (1997) viewed from above. California Academy of Sciences locality 29040. Upper scale bar in centimeters. 


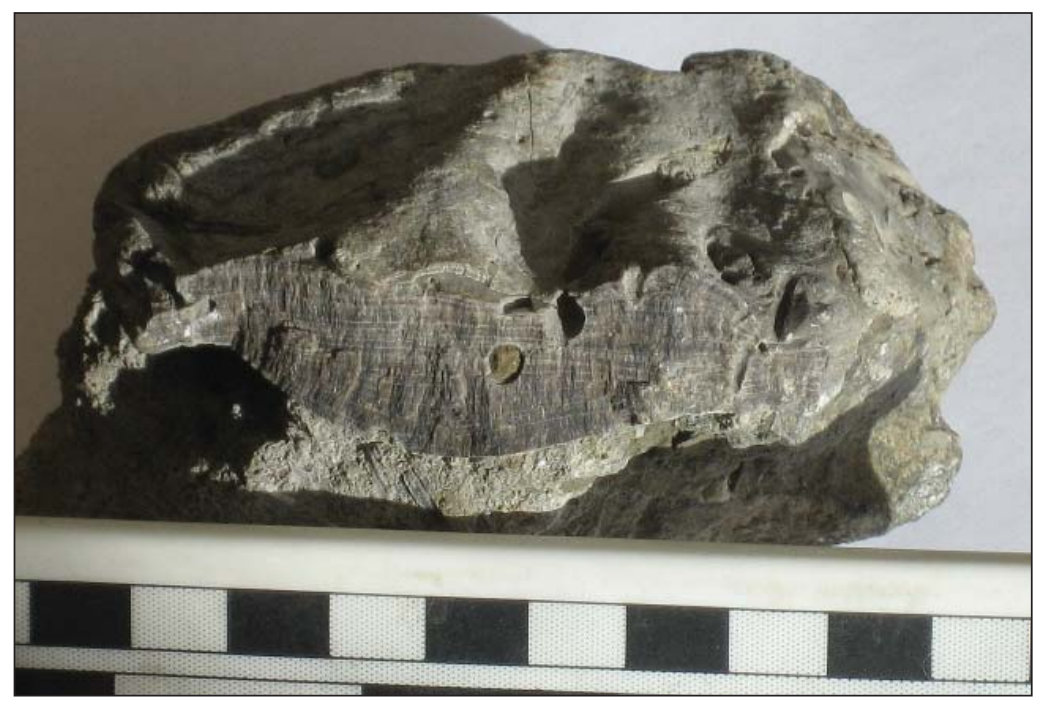

Figure 14. Oblique view of large oyster shell with borings. Note well-developed shell structure. California Academy of Sciences locality 29821. Scale in centimeters.

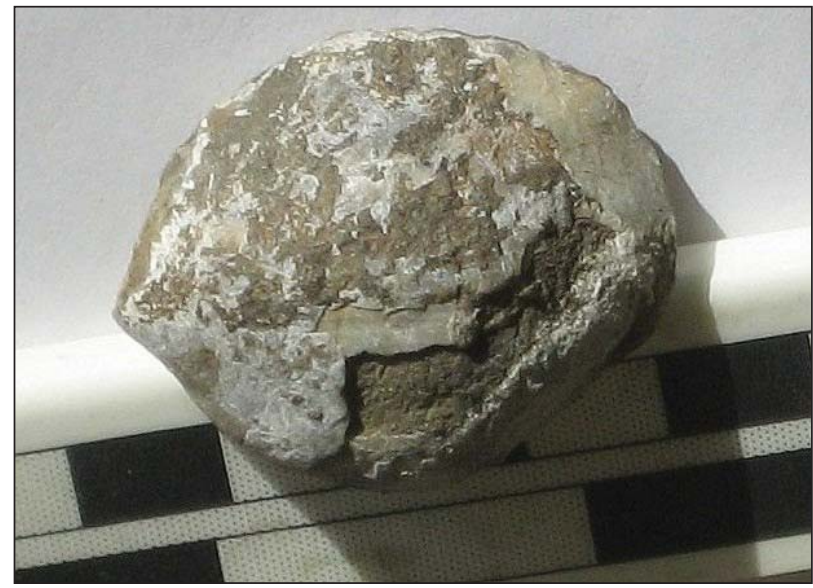

Figure 15. Ventral view of articulated smooth terebratulid brachiopod from California Academy of Sciences locality 29523. Inner scale marked in centimeters.

Figure 16. Smooth terebratulid brachiopod (ventral valve) with well-developed radial color pattern. This is the first time this feature has been observed in a Triassic brachiopod from North America, although they are commonly illustrated in European faunas of the same age. Locality 07RB14, upper part of the nodular limestone member of the Kamishak Formation. Scale in centimeters.

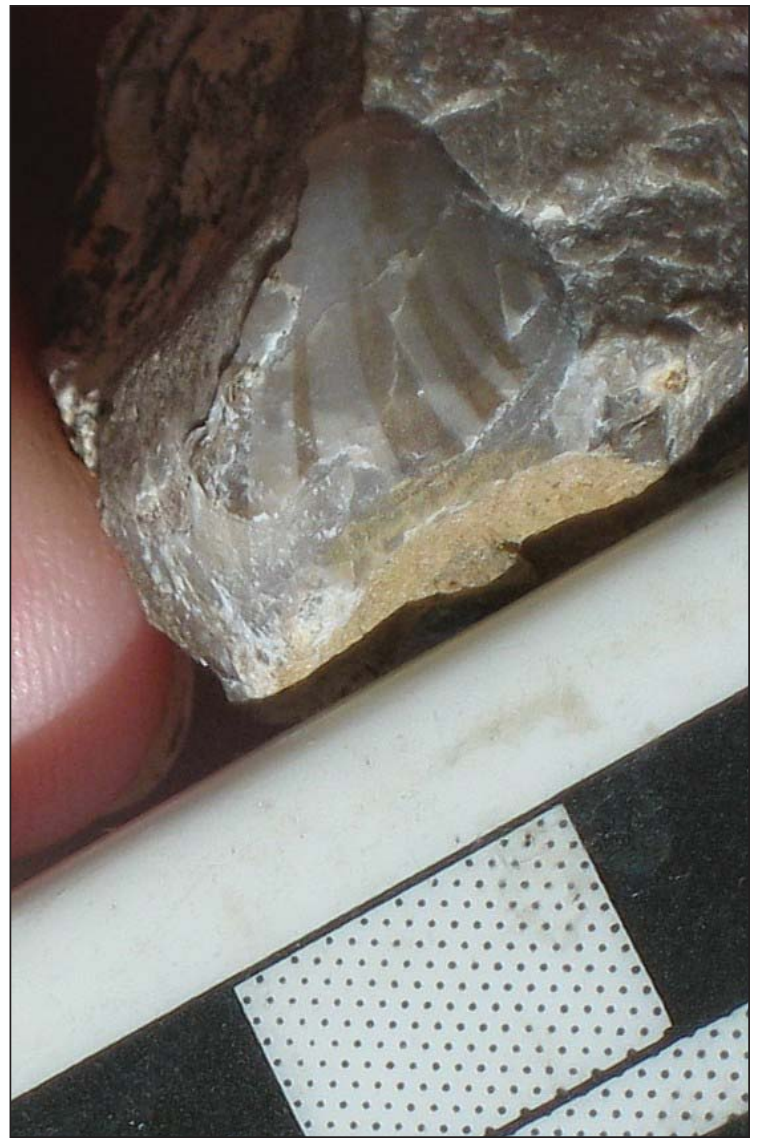


Crinoids-No articulated crinoids are known from the Kamishak Formation in the study area, however, isolated crinoid ossicles are relatively common in the biostromal member of the Kamishak Formation and are present to a lesser degree in the biostromal member. No crinoid ossicles were observed in the platy limestone. The most notable among the ossicle morphotypes include the pentagonal-shaped ossicles of the crinoid genus Pentacrinus (fig.17).

Foraminiferida - No foraminifers have been reported from the Kamishak Formation in the study area, although their presence has been noted in underlying Permian strata (Hanson, 1957; Jeffords, 1957) and overlying Lower Jurassic strata (Amoco Production Co., unpublished internal paleontologic report).

Gastropods-Gastropods are very common in the biostromal member, and slightly less so in the nodular limestone member. Gastropods are not known from the platy limestone and shale member of the Kamishak Formation. Most of the taxa are indeterminate, represented primarily by internal molds (steinkerns), probably due to the non-preservation of the originally aragonitic shell that characterizes most members of this class. However, many differing morphotypes are noted,

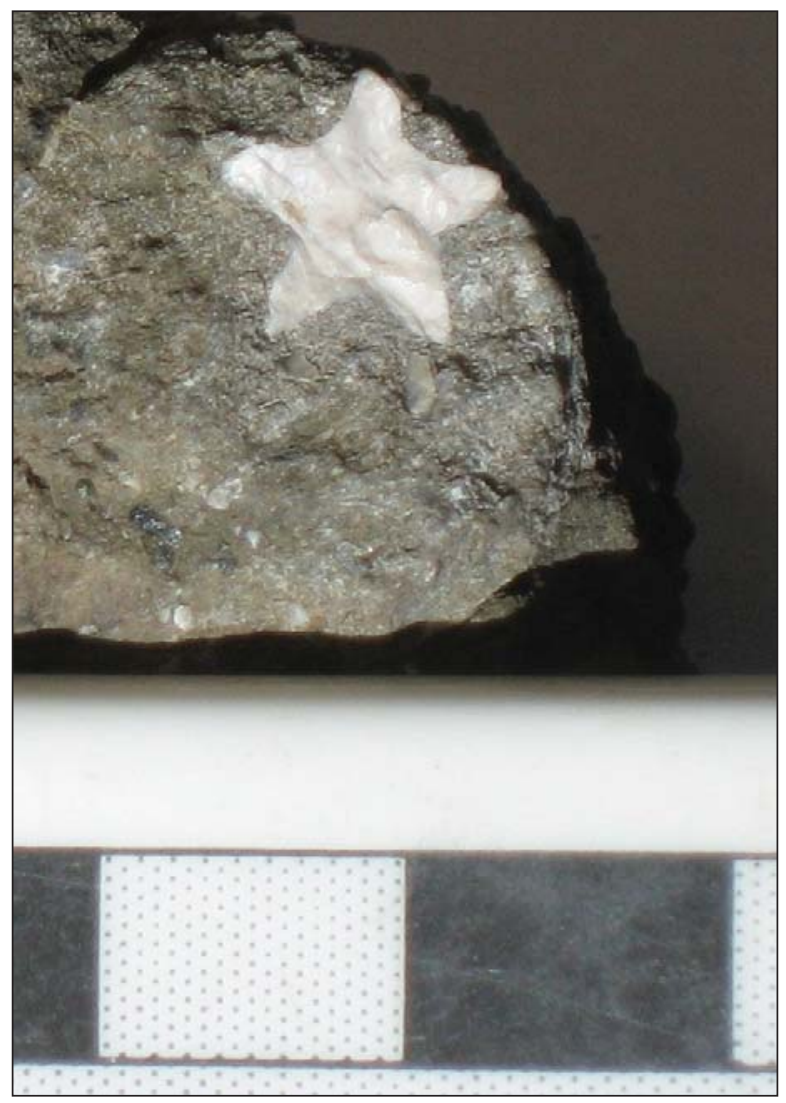

Figure 17. Pentagonal (star) shaped ossicles of the crinoid genus Pentacrinus, California Academy of Sciences locality 29820. Scale marked in centimeters. including both high-spired and low-spired forms. Moldic preservation is rather typical of the nodular limestone member, while preservation of original (or silica-replacement) is more common in the lower biostromal member. The best gastropod material appears to have been collected by geologists of Humble Oil \& Refining Co. These were illustrated in several internal company reports and included a gastropod identified as Protorcula alaskana Smith, 1927. This species is now recognized as the type species of the genus Chulitnacula Frýda and Blodgett, 2001, a genus known from the Chulitna, Alexander, and Farewell terranes of southern Alaska (Frýda and Blodgett, 2001; Blodgett and others, 2000, 2003, 2005, 2006; Blodgett in McRoberts and Blodgett, 2002). Gastropods remain a fruitful target for future paleontological study of the Kamishak Formation. Their utility includes both biostratigraphic and paleoecologic aspects, but is especially useful for determination of paleobiogeographic affinities.

Hydrozoans-The spherical, probably planktonic hydrozoan genus Heterastridium occurs commonly in the lower part of the platy limestone "member" of the Kamishak Formation at Puale Bay. Illustrated in figure 18 are several specimens from collections made by Standard Oil Co. of California geologists (now part of the collections of the California Academy of Sciences in San Francisco).

The earliest reported specimens recognized now as belonging to Heterastridium were by USGS paleontologist T.W. Stanton, who identified them in Capps (1923, p. 93) as Stoliczkaria sp. related to S. granulata. As noted here, Heterastridium commonly occurs in the lower part of the platy limestone and shale member and is the only associated fossil commonly found together with the more abundant Monotis (Pacimonotis) subcircularis Gabb. Heterastridium, a genus restricted to the Upper Triassic, is commonly thought to be indicative of a tropical, warm-water paleoenvironment (Zhang and others, 2003), and is found in a number of accreted terranes of southern Alaska (Chulitna, Wrangellia, Farewell [Nixon Fork subterrane], Alexander, and Peninsular). Its occurrence in Alaska was first noted by Smith (1927) and its most northerly undoubted report in accretionary terrane collage of southern Alaska is from the Nixon Fork subterrane of the Farewell terrane (Silberling and others, 1997).

Nautiloids-Nautiloids have been noted by the writer as being relatively common in the nodular limestone member. The specimens this author has observed are represented by relatively large internal molds. The genus Indonautilus? was reported from the Kamishak Formation exposures in the study area previously by N.J. Silberling (in an E\&R report to G.W. Moore, dated Nov. 23, 1965). In his monographic treatment of American Triassic coiled nautiloids, Kummel (1953, 


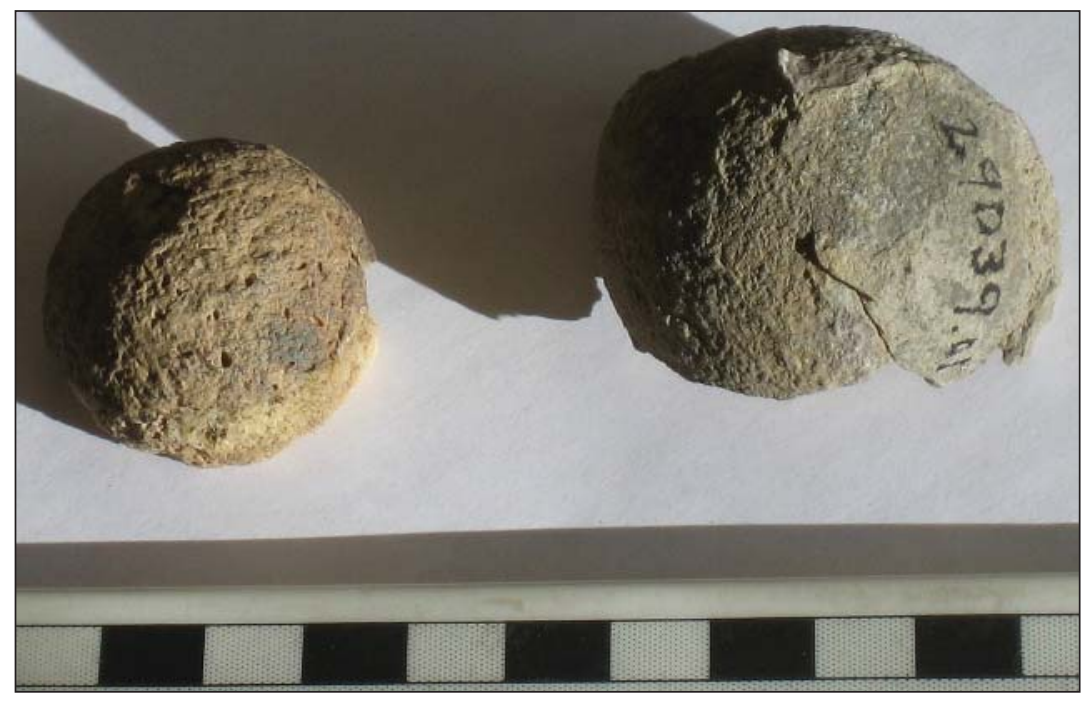

Figure 18. Two specimens of the spherical hydrozoan genus Heterastridium. California Academy of Sciences locality 29039-01. Limestone and shale member of the Kamishak Formation. Scale marked in centimeters.

p. 31) described but did not illustrate a single nautiloid he identified as Germanonautilus sp. His description is as follows:

"Two specimens are available for study from Alaska that clearly belong in Germanonautilus but are too incomplete to warrant specific assignment. The first, U.S.N.M. 107092 (U.S.G.S. loc. 12393), is from the Gold [sic] Bay District, Alaska Peninsula, Alaska and was collected by W.R. Smith in 1924. The specimen is an essentially complete living chamber with part of the crushed phragmocone. The conch is very robust, measuring $57 \mathrm{~mm}$ in width and $54 \mathrm{~mm}$ in height on the most adoral part of the living chamber. The venter is broadly rounded, flanks slightly convex grading on to a rounded and sloping umbilical wall. There is a broad shallow constriction on the flanks and venter about 2 $\mathrm{cm}$ back of the most adoral part of the specimen. The phragmocone is badly crushed but appears to be very much smaller in its general dimensions than the living chamber, indicating a rapidly expanding conch. Only part of a broad lateral lobe of the suture is visible. Position of the siphuncle is not known."

The specimen studied by Kummel was earlier referred to as Nautilus sp. by T.W. Stanton in Smith (1926, p. 68). Several large nautiloids were recovered during the 2007 field season from locality 07RB11 and these are probably conspecific with that described by Kummel as Germanonautilus sp.

Scleractinian corals — Scleractinian corals are known only from the biostromal and nodular members of the Kamishak Formation in the study area. Many of the species appear to belong to colonial forms (fig. 19), and include a form assigned to Elysastraea sp., the only coral taxon yet assigned generically in the study area. Other larger taxonomic entities have been recognized, including thamnasteriid corals, montlivaltid corals, and fungiid? corals. Solitary scleractinian corals have been observed at localities 07RB10 and 07RB12, and $07 \mathrm{RB} 14$.

Spongiomorphs-Spongiomorphs are common in the biostromal member of the Kamishak Formation (Wang, 1987), but have not been reported in the other members. No formal systematic study has yet been undertaken for this group in the study area.

Conodonts-Conodonts had not previously been reported from the Kamishak Formation. Three limestone samples were collected during the 2007 DGGS summer field season for conodont analysis (from 07RB08, 11, and 13B), but only one sample yielded positive results (07RB11). From the latter locality, one indeterminate, possibly juvenile conodont Pa element blade fragment was recovered that had a color alteration index (CAI) value of 1.5-2 (Andrea Krumhardt, written commun., November 14, 2007). This value indicates the host strata were buried to a point lower in the oil window. Conodont color alteration data (Epstein and others, 1977) are highly desired as they would provide another mode of geothermometry to unravel the thermal history of this area.

Vertebrates-No vertebrates have been noted previously from the Triassic rocks of the Peninsular terrane. During the summer 2007 DGGS field program a single large rib fragment approximately 3.9 in $(10 \mathrm{~cm})$ long was recovered from near the base of the nodular limestone member of the Kamishak Formation at the author's locality 07RB11. The specimen consists of a long curved bone that was preserved as an external mold in lime mudstone. Rubber latex casts were made for detailed examination (fig. 20). One cast was sent to Thomas L. Adams, a graduate student at Southern Methodist University, who recently completed a M.S. thesis study of Late Triassic vertebrate (dominantly ichthyosaur) material from middle Norian strata of the Hound Island 


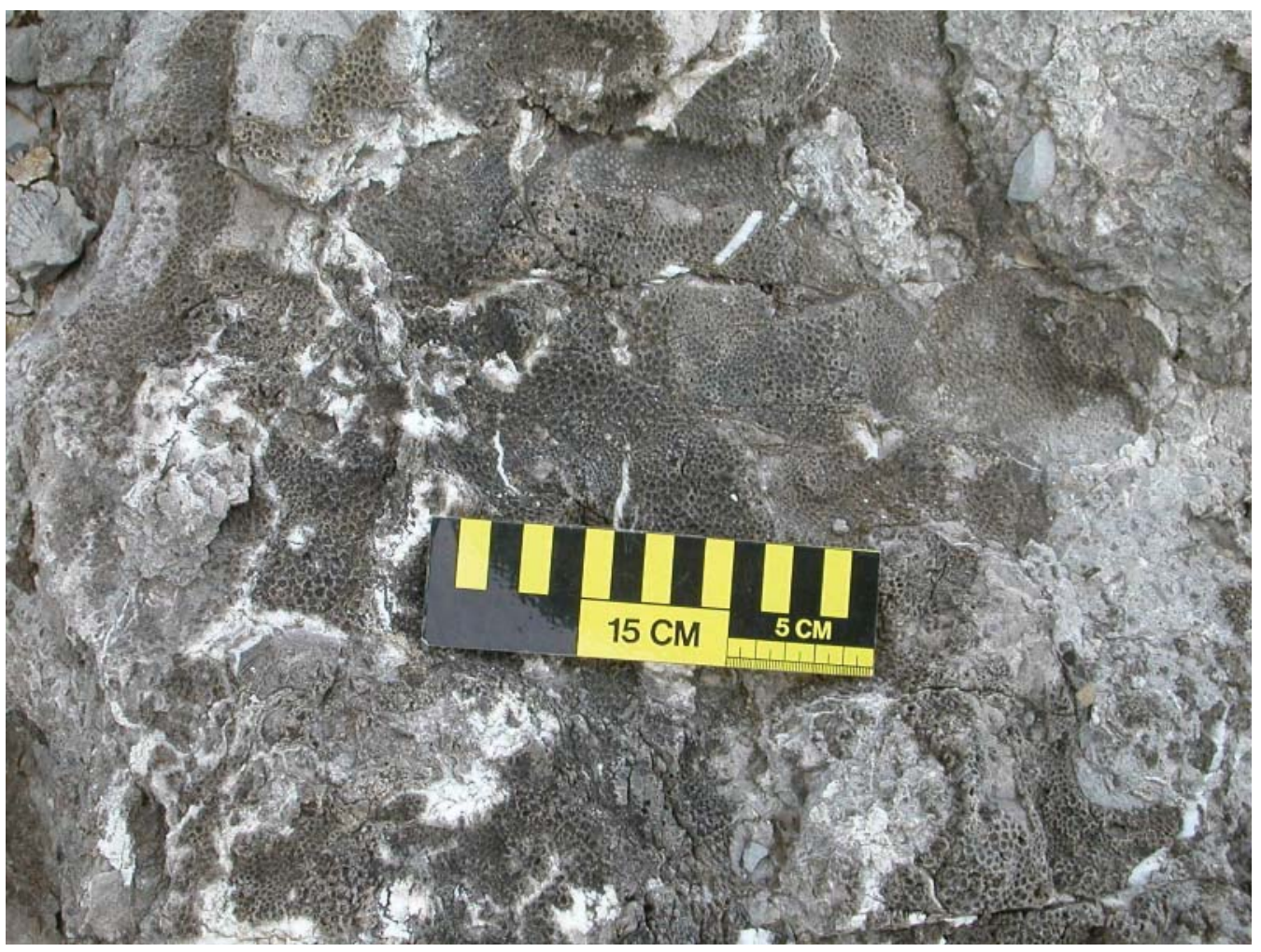

Figure 19. Massive, colonial scleractinian coral head on bedding surface in the uppermost part of the biostromal member of the Kamishak Formation (near fossil locality 07RB10, Lat. 57²42.825’ N, Long. $\left.155^{\circ} 21.712^{\prime} W\right)$.

Volcanics on Hound Island in the Keku Strait region of southeastern Alaska. Based on his preliminary examination of the cast, he reports: "At first inspection, it is definitely a rib. My first guess would be to say that it is ichthyosaur, based on size and the furrow along the upper surface. Beyond that it is hard to say. Ribs are not very diagnostic. Always the chance that it could be thalattosaur or even sauropterygian” (T.L. Adams, written commun., October 2, 2007). Although I am not a vertebrate paleontologist, I would comment further that this specimen reminds me very much of ichthyosaur rib fragments I have seen in the Upper Jurassic Naknek Formation from the east shore of the Island Arm branch of Becharof Lake.

\section{PALEOBIOGEOGRAPHIC AFFINITIES OF THE PENINSULAR TERRANE TRIASSIC FAUNAS}

Determination of the paleobiogeographic affinities of Peninsular terrane faunas and floras through time will shed much light on the wanderings of this terrane during Permian through Jurassic time up to its final accretion into the collage of terranes that comprise Alaska as we now know it. Virtually nothing has previously been published regarding the Peninsular terrane affinities during the Late Triassic, but enough data are now emerging so that some speculation can be made. The remarks made below pertain only to Kamishak Formation fauna recovered to date from the Puale Bay-Alinchak Bay area.

The study of the paleobiogeographic affinities of Late Triassic faunas from Alaska has only recently been undertaken. The first papers to address this issue have focused on monotid bivalves (Silberling, 1985; Grant-Mackie and Silberling, 1990; and Silberling and others, 1997). More recently, publications have appeared that examined the faunal distribution of Late Triassic gastropods within Alaska (Blodgett and Frýda, 2001a, b; Blodgett and others, 2001, 2003, 2005, 2006; Frýda and Blodgett, 2001; Sandy and others, 2001 [the latter also addressed brachiopods]).

The relative abundance of the floating hydrozoan genus Heterastridium (primarily known from late Norian strata in North American, but older Norian records in New Zealand and New Caledonia exist [Jack GrantMackie, written commun., July 24, 2007]) suggest a warm, tropical setting for the terrane. Heterastridium is found in a number of accreted terranes of southern Alaska (Chulitna, Alexander, Wrangellia, Peninsular, Susitna, and Farewell) where it is often closely associated with strata bearing other warm-water elements such as scleractinian corals, spongiomorphs, and 


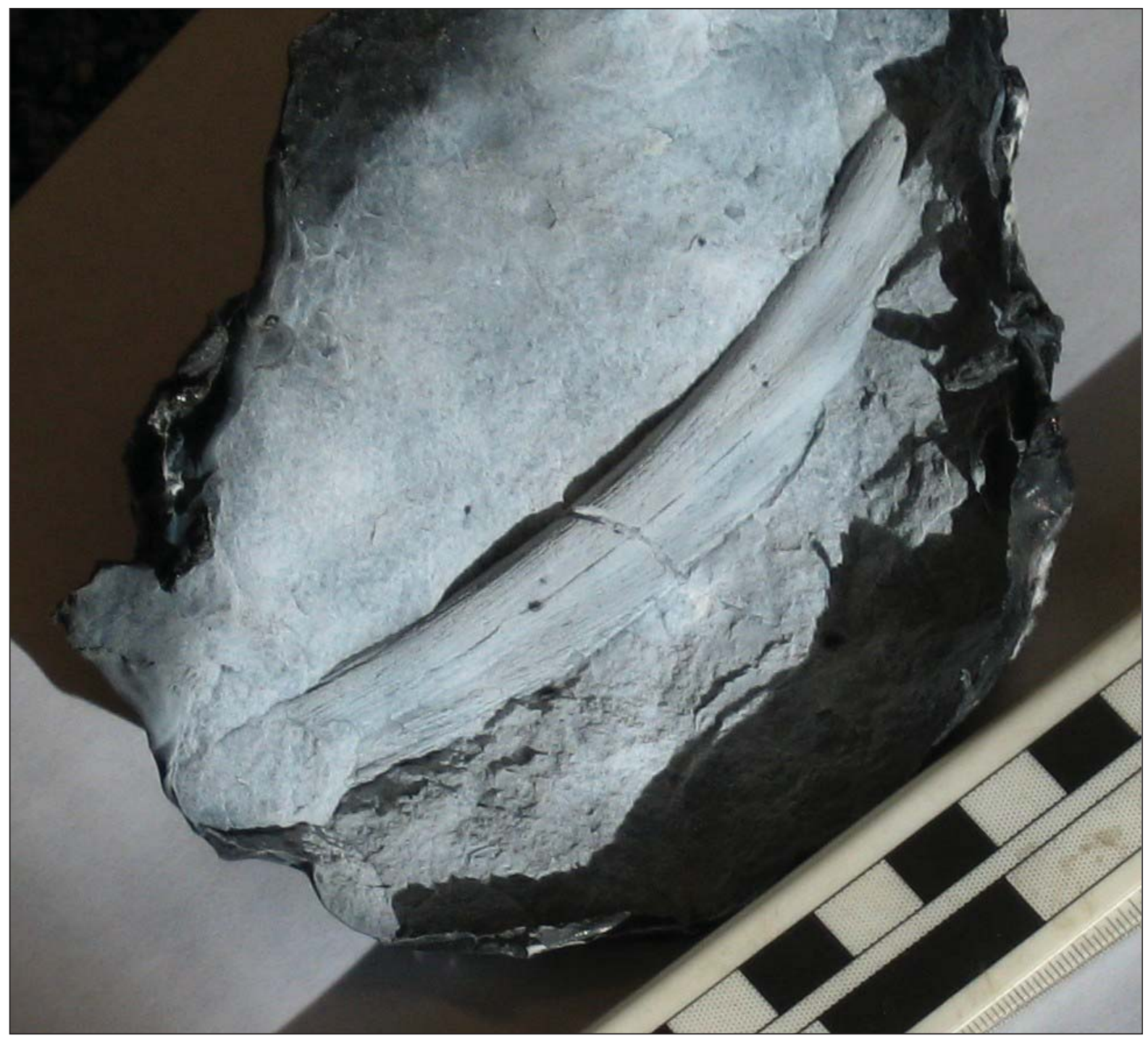

Figure 20. Rubber latex replica of probable ichthyosaur rib fragment from locality 07RB11. Upper scale bar in centimeters.

calcareous green algae (Zhang and others, 2003). The most northerly occurrence of Heterastridium in North America is the accretionary Farewell (Nixon Fork) terrane of west-central Alaska (Silberling and others, 1997, p. 16). Heterastridium, along with scleractinian corals and spongiomorphs, are unknown in the Arctic Alaska terrane, which appears to have been situated at a much more northerly, cool paleolatitude.

Monotid bivalves, the key faunal signature to the upper limestone and shale member of the Kamishak Formation in the study area, have until this investigation been considered to belong to only two species, Monotis (Pacimonotis) subcircularis Gabb, typical of the lower part of this member, with rarer occurrences of Monotis (Monotis) alaskana Smith higher in the section (Detterman and others, 1996; Silberling and others, 1997). Silberling and others (1997, fig. 4) show only four southern Alaskan terranes that contain such a combination of species (present with qualification, or present in the sense of "cf." or "?”): the Susitna, Wrangellia, Peninsular, and Alexander terranes. As noted above, two of the California Academy of Sciences collections (CAS localities 28040 and 29823) recently obtained on loan, contain several left valves of monotid bivalves that are identical to forms illustrated and identified as Monotis (Entomonotis) sp. cf. M. (E.) ochotica densistriata (Teller, 1886) of Silberling, and others, 1997. This taxon has previously been recognized in Alaska only from USGS Mesozoic locality 1912 on Kuiu Island, southeast Alaska (in the Alexander terrane).

Although few gastropods are identified with any confidence from Kamishak Formation in the study area, it is of note that the species Protorcula alaskana was identified and illustrated in an internal report of 
the Humble Oil \& Refining Co. (Levinson and Jeffords, 1956). This species was later designated the type species of the genus Chulitnacula Frýda and Blodgett, 2001, a genus known only from the Chulitna, Alexander, and Farewell terranes of southern Alaska (Frýda and Blodgett, 2001; Blodgett and others, 2000, 2003, 2005, 2006; Blodgett in McRoberts and Blodgett, 2002). It is particularly noteworthy that this distinctive species is, as far as is known, absent from the Wrangellia terrane. Assessment of the Norian gastropod populations (together with other associated fauna and flora) from various parts of southern Alaska suggests that all were probably situated in warm, equatorial settings during this time. However, the Wrangellia terrane (with its own distinctive, highly endemic gastropod fauna) was separated by some significant distance from the Chulitna, Alexander, and Farewell terranes, which appear to have formed a triplet (probably situated close to one another) sharing many of the same, highly endemic gastropod species (see gastropod references cited above for more detailed description). The paleobiogeographic evidence at hand indicates that the Peninsular terrane shares many affinities with the Alexander, Chulitna, and Farewell terrane, rather than with the Wrangellia terrane.

\section{ACKNOWLEDGMENTS}

First, I want to thank Rocky R. Reifenstuhl for involving me in three separate field seasons of fieldwork on the Alaska Peninsula, two of which permitted me to visit the Upper Triassic Kamishak Formation exposures in the area of Puale Bay and Cape Kekurnoi. Many other people have also made contributions that have helped me to better understand the rocks of the area. Les Magoon (USGS, Menlo Park, CA) and Bob Egbert (formerly USGS in Menlo Park, now a consultant in Houston, TX) are gratefully acknowledged for their discussions and sharing with me their notes and photographs from their 1979 fieldwork in the study area. Frederic H. ("Ric") Wilson (USGS, Anchorage, AK) graciously allowed me access to the field sheets and field notes of the late Robert L. ("Buck") Detterman that he made while mapping in the study area. Norman J. Silberling proved very helpful in providing insights in the classification of monotid bivalves and providing me access to the illustrated type specimens from the monographic treatment and overview of this group that he, Jack Grant-Mackie, and Kathy Nichols beautifully documented in their paper (Silberling and others, 1997) on this group. I thank Bryan Sralla (XTO Energy, Inc., Fort Worth, TX) for many fruitful discussions on the Mesozoic stratigraphy and petroleum potential of the region. I also wish to thank the following people for providing access to archived fossil collections and literature of this region: Jean F. DeMouthe (California Academy of Sciences, San Francisco, CA), K.C. (“Casey”) McKinney (USGS, Denver, CO), and
Keith A. Knabe (ExxonMobil Exploration Co., Houston, TX). Kenneth M. Dixon, USGS, Anchorage, Alaska, was most helpful in scanning many old diagrams and in photographing some of the newly collected material reported here. This paper benefited from the thoughtful reviews of Arthur J. Boucot (Dept. Zoology, Oregon State University, Corvallis, OR) and David M. Rohr (Dept. Geology, Sul Ross State University, Alpine, TX). Finally, I thank Herb Mann of Houston, Texas, (formerly with Shell Oil Co.) for sharing his wonderful recollections of fieldwork in the 1950s on the Mesozoic stratigraphy of the Puale Bay area.

\section{REFERENCES CITED}

Barbacka, Maria, Pálfy, J., and Smith, P.L., 2006, Hettangian (Early Jurassic) plant fossils from Puale Bay (Peninsular terrane, Alaska): Review of Palaeobotany and Palynology, v. 142, p. 33-46.

Blodgett, R.B., and Frýda, J., 2001a, On the occurrence of Spinidelphinulopsis whaleni (Late Triassic [early Norian] Gastropoda) in the Cornwallis Limestone, Kuiu Island, southeastern Alaska (Alexander terrane) and its paleobiogeographic significance: Bulletin of the Czech Geological Survey, v. 76, no. 4, p. 235-242.

2001b, Upper Triassic gastropod biogeography of western North America [abs.]: Geological Society of America Abstracts with Programs, v. 33, no. 3, p. A-53.

Blodgett, R.B., and Sralla, Bryan, 2008, A major unconformity between Permian and Triassic strata at Cape Kekurnoi, Alaska Peninsula; Old and new observations on stratigraphy and hydrocarbon potential, in Haeussler, P.J., and Galloway, J.P., eds., Studies by the U.S. Geological Survey in Alaska, 2006: U.S. Geological Survey Professional Paper 1739-E, 13 p. [http://pubs.usgs.gov/pp/pp1739/e/].

Blodgett, R.B., Frýda, J., and Stanley, G.D., Jr., 2001, Delphinulopsidae, a new neritopsoidean gastropod family from the Upper Triassic (upper Carnian or lower Norian) of the Wallowa terrane, northeastern Oregon: Journal of Czech Geological Society, v. 46, no. 3-4, p. 307-318.

2003, Late Triassic gastropod biogeography of southern Alaskan accreted terranes [abs.]: Geological Society of America Abstracts with Programs, v. 35, no. 4, p. 59.

2005, Upper Triassic gastropod fauna from southern Alaska and its implications for terrane accretion [abs.]: Geological Society of America Abstracts with Programs, v. 37, no. 7, p. 82.

2006, Late Triassic gastropod faunas of western North America-A useful tool in terrane analysis [abs.]: Geological Society of America Abstracts with Programs, v. 38, no. 5, p. 81. 
Blodgett, R.B., Wilson, F.H., Stanley, G.D., Jr., McRoberts, C.A., and Sandy, M.R., 2000, Upper Triassic stratigraphy and fauna of the Taylor Mountains D-2 and D-3 quadrangles (SW part of the Farewell terrane), southwest Alaska [abs.]: Geological Society of America Abstracts with Programs, v. 32, no. 6, p. A-4.

Capps, S.R., 1923, The Cold Bay district, in U.S. Geological Survey Staff, Mineral resources of Alaska, report on progress of investigations in 1921: U.S. Geological Survey Bulletin 739, p. 77-116, 1 plate, scale 1:250,000.

Detterman, R.L., and Hartsock, J.K., 1966, Geology of the Iniskin-Tuxedni region, Alaska: U.S. Geological Survey Professional Paper 512, 78 p., 6 plates, scale 1:63,360.

Detterman, R.L., and Reed, B.L., 1980, Stratigraphy, structure, and economic geology of the Iliamna Quadrangle, Alaska: U.S. Geological Survey Bulletin 1368-B, 86 p., 1 plate, scale 1:250,000.

Detterman, R.L., Case, J.E., Miller, J.W., Wilson, F.H., and Yount, M.E., 1996, Stratigraphic framework of the Alaska Peninsula: U.S. Geological Survey Bulletin 1969-A, 74 p.

Detterman, R.L., Case, J.E., Wilson, F.H., and Yount, M.E., 1987, Geologic map of the Ugashik, Bristol Bay, and western part of Karluk quadrangles, Alaska: U.S. Geological Survey Miscellaneous Investigations Series Map 1685, 1 plate, scale 1:250,000.

Detterman, R.L., Case, J.E., Wilson, F.H., Yount, M.E., and Allaway, W.H., Jr., 1983, Generalized geologic map of the Ugashik, Bristol Bay, and part of Karluk quadrangles, Alaska: U.S. Geological Survey Miscellaneous Field Studies Map 1539-A, 1 plate, scale 1:250,000.

Epstein, A.G., Epstein, J.B., and Harris, L.D., 1977, Conodont color alteration-An index to organic metamorphism: U.S. Geological Survey Professional Paper 995, 27 p.

Fischer, P.H., 1872, Sur quelques fossiles de l'Alaska, rapportés par. M.A. Pinart: Comptes Rendus, v. 75, p. 1,784-1,786.

1875, Sur quelques fossiles de l'Alaska, in Pinard, A.L., Voyages à la côte nord-ouest de l'Amérique executés dans les années 1870-1872: Paris, E. Leroux, pt. 1, p. 33-36.

Frech, Fritz, 1908, Die zircumpacifische Trias; Lethaea geognostica, Teil 2, Das Mesozoicum: Band 1, Trias, v. 4, p. 488-509.

Frýda, J., and Blodgett, R. B., 2001, Chulitnacula, a new paleobiogeographically distinctive gastropod genus from Upper Triassic strata in accreted terranes of southern Alaska: Journal of Czech Geological Society, v. 46, no. 3-4, p. 299-306.
Gabb, W.M., 1864, Description of Triassic fossils of California and the adjacent territories: California Geological Survey, Paleontology, v. 1, p. 17-35, plates 3-6.

Grant-Mackie, J.A., and Silberling, N.J., 1990, New data on the Upper Triassic bivalve Monotis in North America and the new subgenus Pacimonotis: Journal of Paleontology, v. 64, no. 2, p. 240-254.

Hanna, G.D., Leach, C.E., Tallant, R.L., Bryan, J.J., and Scott, E.W., 1937, Preliminary geologic report on the Bear Creek Anticline, Alaska-1937: San Francisco, Tide Water Associated Oil Co.-Standard Oil Co. of California-Union Oil Co. of California internal report, $20 \mathrm{p}$.

Hanson, B.M., 1957, Middle Permian limestone on Pacific side of Alaska Peninsula: American Association of Petroleum Geologists Bulletin, v. 41, no. 10, p. 2,376-2,378.

Imlay, R.W., 1981, Early Jurassic ammonites from Alaska: U.S. Geological Survey Professional Paper 1190, 40 p.

Imlay, R.W., and Detterman, R.L., 1977, Some Lower and Middle Jurassic beds in Puale Bay-Alinchak Bay area, Alaska Peninsula: Bulletin of the American Association of Petroleum Geologists, v. 61, no. 4, p. 607-611.

Jeffords, R.M., 1957, Permian fossils from an island in Puale Bay, Alaska: Houston, Humble Oil \& Refining Co. Geologic Research Report 57-24, 6 p.

Kelley, J.S., 1980, Environments of deposition and petrography of Lower Jurassic volcaniclastic rocks, southwestern Kenai Peninsula, Alaska: Davis, University of California, Ph.D. thesis, 304 p.

Kellum, L.B., 1945, Jurassic stratigraphy of Alaska and petroleum exploration in northwest America: Transactions of the New York Academy of Science, ser. 2, v. 7, no. 8, p. 201-209.

Kummel, Bernhard, 1953, American Triassic coiled nautiloids: U.S. Geological Survey Professional Paper 250, 104 p., 19 plates.

Levinson, S.A., and Jeffords, R.M., 1956, Megafossils and spores and pollen from Puale Bay, Alinchak Bay, and Cape Kekurnoi, Alaska: Houston, Humble Oil \& Refining Co. Geologic Research Report, 10 p., 4 plates.

Martin, G.C., 1915, The western part of Kenai Peninsula, in Martin, G.C., Johnson, B.L., and Grant, U.S., Geology and mineral resources of Kenai Peninsula, Alaska: U.S. Geological Survey Bulletin 587, p. 41-112.

Martin, G.C., 1916, Triassic rocks of Alaska: Geological Society of America Bulletin, v. 27, p. 685-718.

Martin, G.C., 1921, Preliminary report on petroleum in Alaska: U.S. Geological Survey Bulletin 719, 83 p., 5 plates, scale 1:125,000. 
Martin, G.C., 1926, The Mesozoic stratigraphy of Alaska: U.S. Geological Survey Bulletin 776, 493 p.

Martin, G.C., and Katz, F.J., 1912, A geologic reconnaissance of the Iliamna region, Alaska: U.S. Geological Survey Bulletin 485, 138 p.

McRoberts, C.A., 1997, Late Triassic (Norian-Rhaetian) bivalves from the Antimonio Formation, northwestern Sonora, Mexico: Revista Mexicana de Ciencias Geológicas, v. 14, no. 2, p. 167-177.

McRoberts, C.A., and Blodgett, R.B., 2002, Upper Triassic (Norian) mollusks from the Taylor Mountains Quadrangle, southwest Alaska, in Wilson, F.H., and Galloway, J.P., eds., Geologic Studies in Alaska by the U.S. Geological Survey, 2000: U.S. Geological Survey Professional Paper 1662, p. 55-75.

Mojsisovics, Edmund, von, 1886, Arktische Triasfaunen: Mémoires de l'Académie Impériale des Sciences de St.-Pétersbourg, 7th ser., v. 33, no. 6, 159 p., 20 plates.

Molenaar, C.M., 1995, Alaska Peninsula, in Magoon, L.B., Molenaar, C.M., Bruns, T.R., Fisher, M.A., Valin, Z.C., Southern Alaska Province (003), in Gautier, D.L., Dolton, G.L., Takahashi, K.I., and Varnes, K.L., eds., 1995 National assessment of United States oil and gas resources-Results, methodology, and supporting data: U.S. Geological Survey Digital Data Series 30, CD-ROM, p. 2-4.

Moore, G.W., 1967, Preliminary geologic map of Kodiak Island and vicinity, Alaska: U.S. Geological Survey Open-file Report 67-161, 1 plate, scale 1:250,000.

Newton, C.R., 1983a, Norian (Late Triassic) mollusks of Cordilleran allochthonous terranes: Paleoecology and paleozoogeography: Santa Cruz, University of California, Ph.D. thesis, 173 p.

1983b, Paleozoogeographic affinities of Norian bivalves from the Wrangellian, Peninsular, and Alexander terranes, northwestern North America, in Stevens, C.H., ed., Pre-Jurassic rocks in western North American suspect terranes: Sacramento, CA, Society of Economic Paleontologists and Mineralogists Symposium, p. 37-48.

Newton, C.R., 1990, Triassic-Jurassic boundary section at Puale Bay, Alaska Peninsula; Comparative diversity patterns of skeletal faunas and trace fossils [abs.]: American Association of Petroleum Geologists Bulletin, v. 74, no. 5, p. 730.

Pálfy, József, 1997, Calibration of the Jurassic time scale: Vancouver, University of British Columbia, Ph.D. dissertation, 180 p.

Pálfy, József, Smith, P.L., Mortensen, J.K., and Friedman, R.M., 1999, Integrated ammonite biochronology and U-Pb geochronometry from a basal Jurassic section in Alaska: Geological Society of America Bulletin, v. 111, no. 10, p. 1,537-1,549.
Pinart, A.L., 1873, Voyage à la côte nord-ouest de l'Amérique d'Ounalashka à Kadiak: Paris, Bulletin de la Société de Géographie, série VI, v. 6, p. 561-580.

Sandy, M.R., Blodgett, R.B., and Frýda, J., 2001, Paleobiogeographic signatures for Upper Triassic brachiopods and gastropods from Kuiu Island and adjacent Keku Strait, SE Alaska [abs.]: Geological Society of America Abstracts with Programs, v. 33, no. 3, p. A-53.

Silberling, N.J., 1985, Biogeographic significance of the Upper Triassic bivalve Monotis in circum-Pacific accreted terranes, in Howell, D.G., ed., Tectonostratigraphic terranes of the Circum-Pacific region: Circum-Pacific Council for Energy and Mineral Resources Earth Sciences Series No. 1, p. 63-70.

Silberling, N.J., Grant-Mackie, J.A., and Nichols, K.M., 1997, The Late Triassic bivalve Monotis in accreted terranes of Alaska: U.S. Geological Survey Bulletin 2151, $21 \mathrm{p}$.

Smith, J.P., 1927, Upper Triassic marine invertebrate faunas of North America: U.S. Geological Survey Professional Paper 141, 262 p.

Smith, W.R., 1925, The Cold Bay-Katmai district, in Mineral resources of Alaska; report on progress of investigations in 1923: U.S. Geological Survey Bulletin 773, p. 183-207.

1926, Geology and oil development of the Cold Bay district, in Mineral Resources of Alaska; Report on progress of investigations in 1924: U.S. Geological Survey Bulletin 783, p. 63-88.

Smith, W.R., and Baker, A.A., 1924, The Cold BayChignik district, in Mineral resources of Alaska; Report on progress of investigations in 1922: U.S. Geological Survey Bulletin 755, p. 151-218.

Sralla, Bryan, and Blodgett, R.B., 2007, Reservoir potential of Late Triassic Kamishak Formation; Puale Bay, Alaska Peninsula [abs.]: American Association of Petroleum Geologists Annual Convention \& Exhibition, Long Beach, CA, 2007, Abstracts, v. 91 (digital), p. 132.

Stanley, G.D., Jr., 1979, Paleoecology, structure, and distribution of Triassic coral buildups in western North America: University of Kansas Paleontological Contributions, v. 65, p. 1-58.

Stanton, T.W., and Martin, G.C., 1905, Mesozoic section on Cook Inlet and Alaska Peninsula: Geological Society of America Bulletin, v. 16, p. 391-410.

Teller, Friedrich, 1886, Die Pelecypod-Fauna von Werchojansk in Ostsiberien, in Mojsisovics, Edmund, von, ed., Arktische Triasfaunen: Mémoires de l'Académie Impériale des Sciences de St.-Pétersbourg, 7th ser., v. 33, no. 6, p. 103-137. 
von Huene, Roland, Moore, J.C., and Moore, G.W., 1979, Cross section of Alaska Peninsula-Kodiak Island-Aleutian Trench: Geological Society of America Map and Chart Series, 1979, v. MC-28A, 2 sheets, scale 1:250,000.

Wang, Jason, 1987, Sedimentology of Norian (Late Triassic) cherts and carbonates from the Peninsular Terrane, Puale Bay, Alaska Peninsula: Syracuse, NY, Syracuse University, unpublished M.S. thesis, $124 \mathrm{p}$.

Wang, Jason, Newton, C.R., and Dunne, L., 1988, Late Triassic transition from biogenic to arc sedimentation on the Peninsular terrane, Puale Bay, Alaska Peninsula: Geological Society of America Bulletin, v. 100 , no. 9 , p. $1,466-1,478$.
Wilson, F.H., Detterman, R.L., and Case, J.E., 1985, The Alaska Peninsula terrane; A definition: U.S. Geological Survey Open-File Report 85-450, 17 p.

Zhang, Ning, Blodgett, R.B., and Stanley, G.D., 2003, Paleontological database applications for Alaskan terrane studies [abs.]: Geological Society of America Abstracts with Programs, v. 35, no. 4, p. 24. 
THIS PAGE INTENTIONALLY LEFT BLANK 


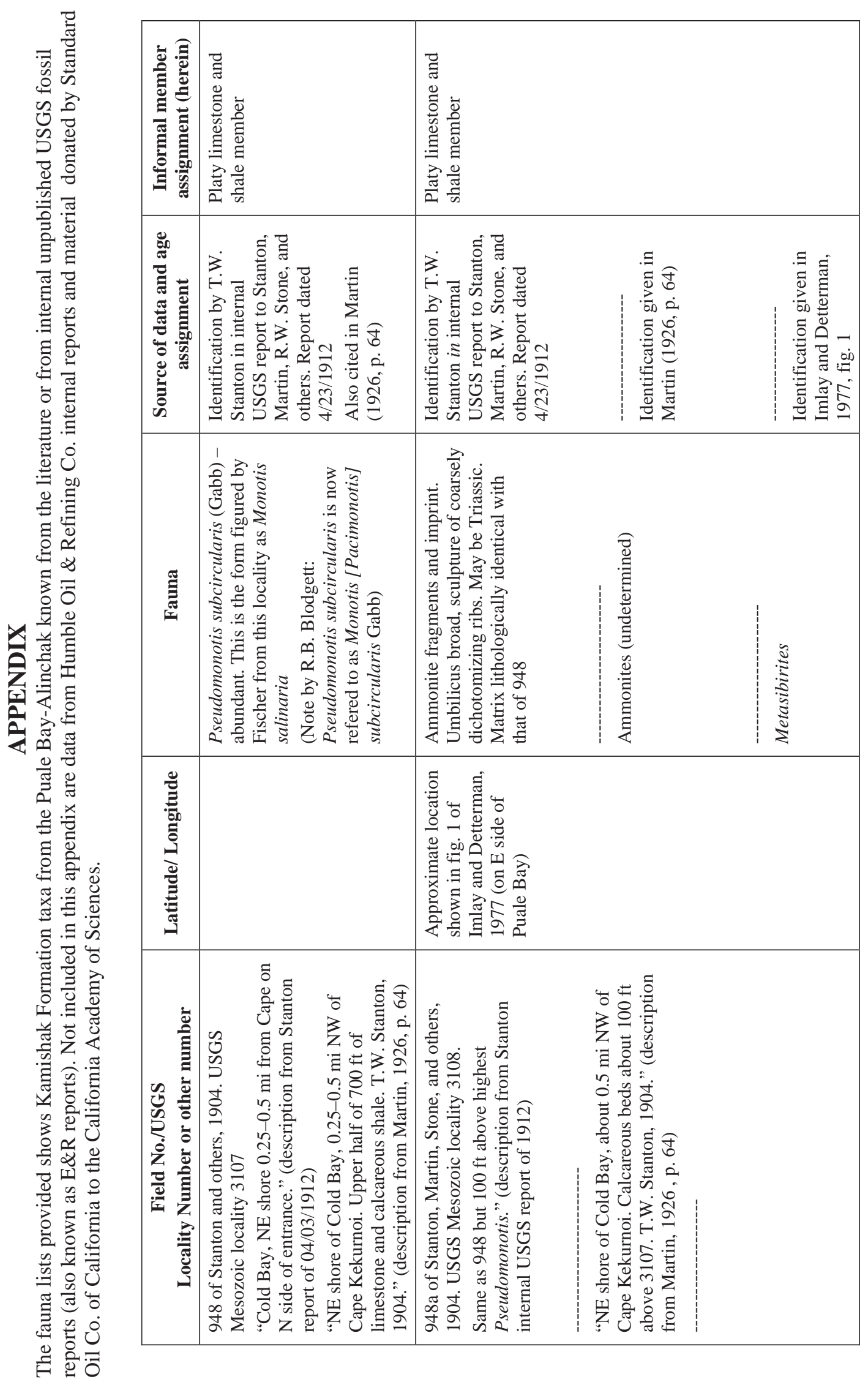




\begin{tabular}{|c|c|c|c|c|}
\hline 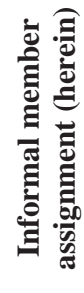 & \multicolumn{2}{|l|}{ 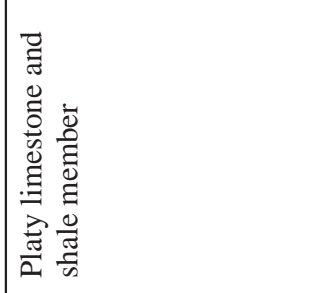 } & 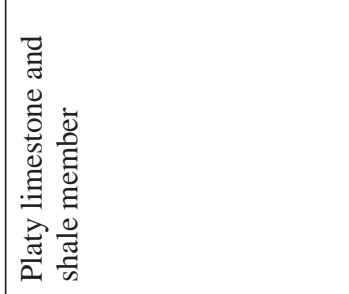 & 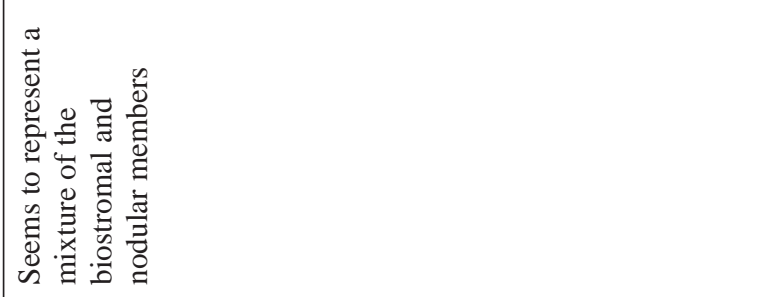 \\
\hline 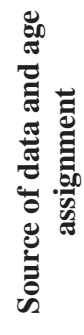 & \multicolumn{2}{|c|}{ 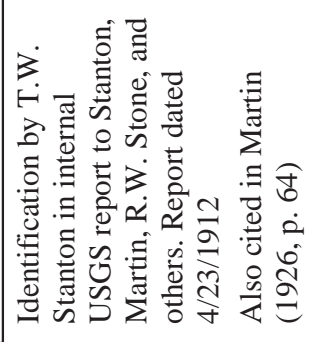 } & 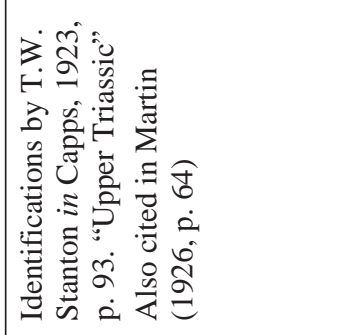 & 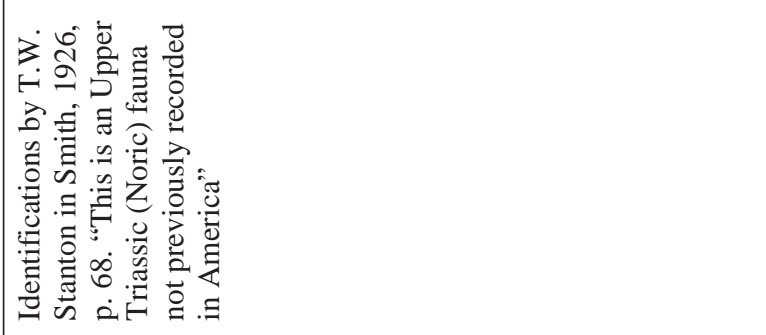 \\
\hline 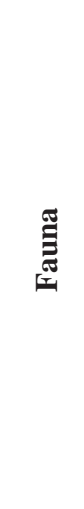 & \multicolumn{2}{|l|}{ 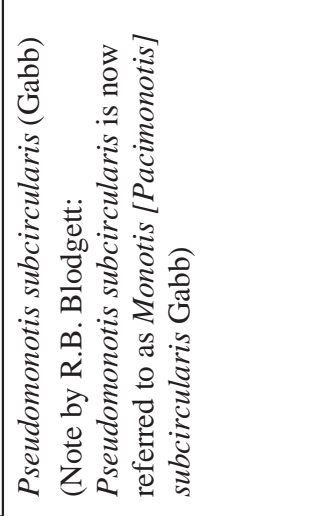 } & 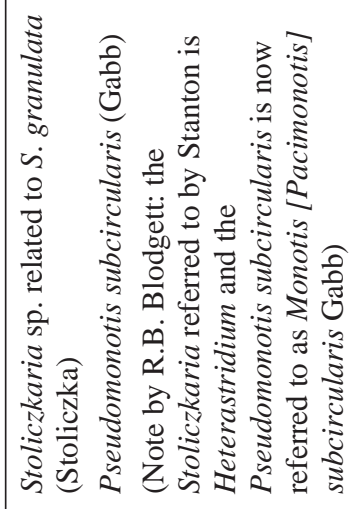 & 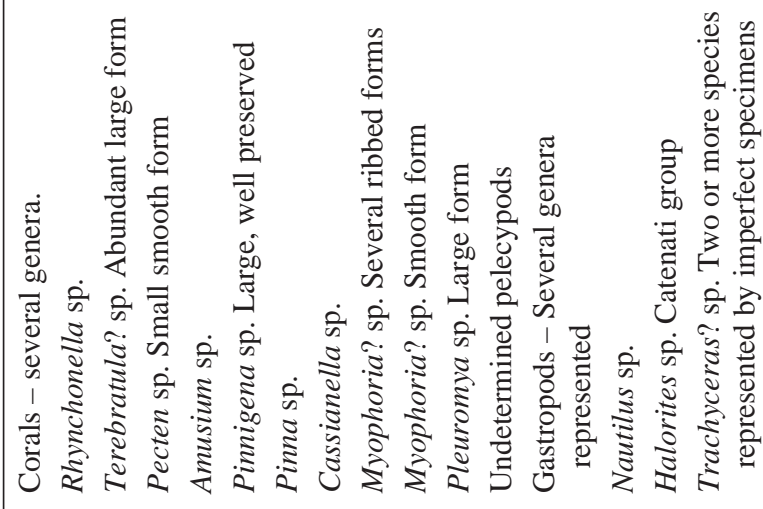 \\
\hline 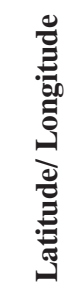 & & & 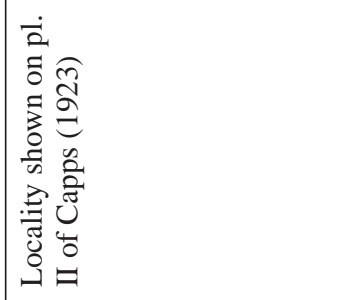 & 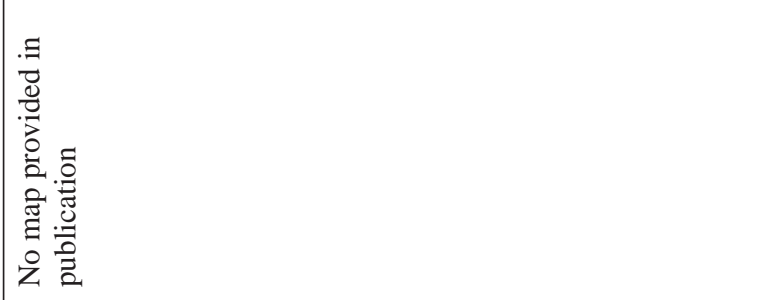 \\
\hline 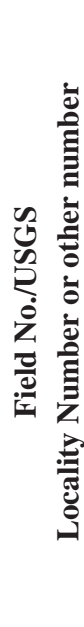 & 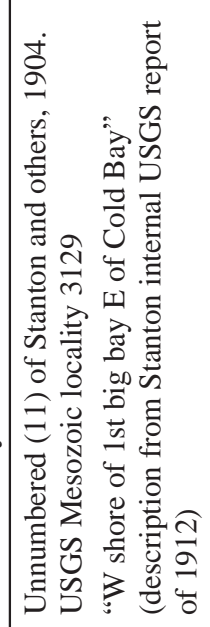 & 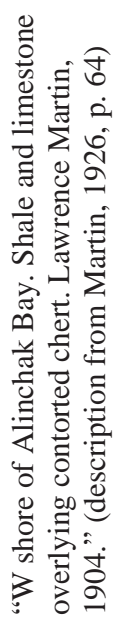 & 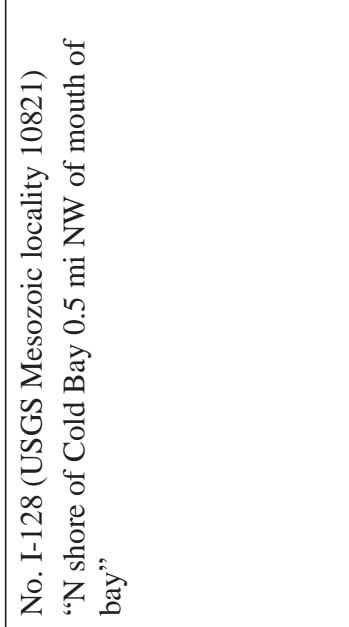 & 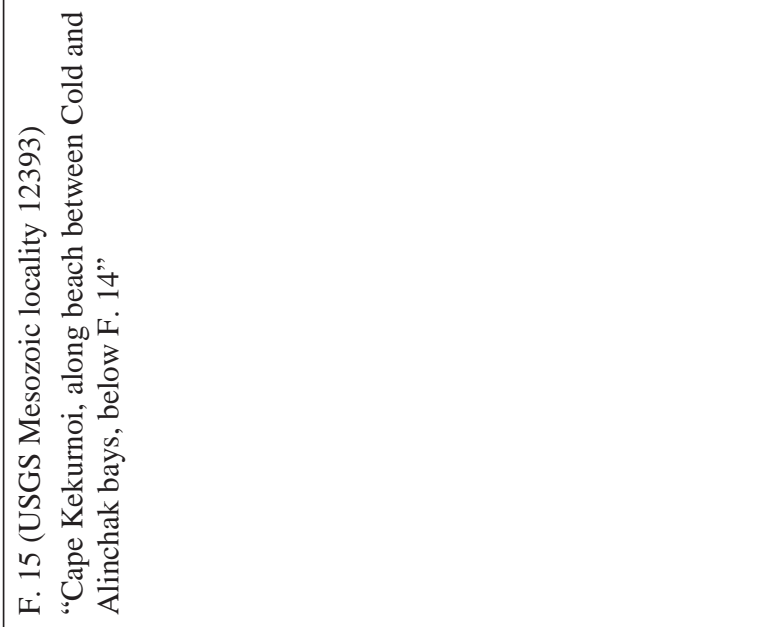 \\
\hline
\end{tabular}




\begin{tabular}{|c|c|c|c|c|}
\hline 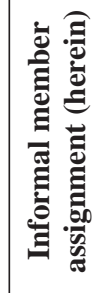 & 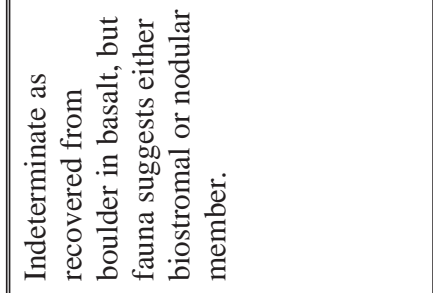 & 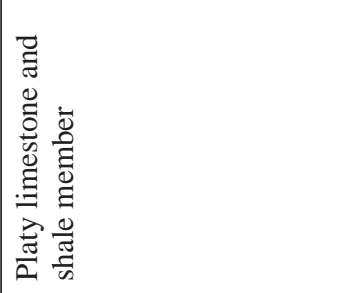 & 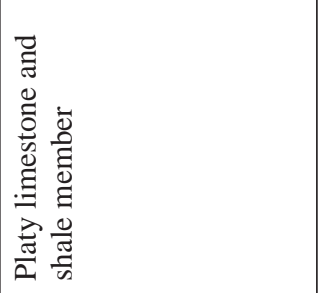 & 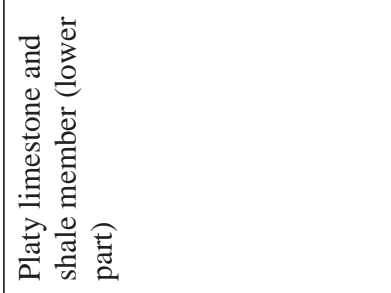 \\
\hline 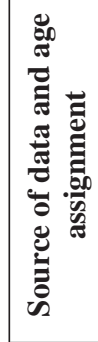 & 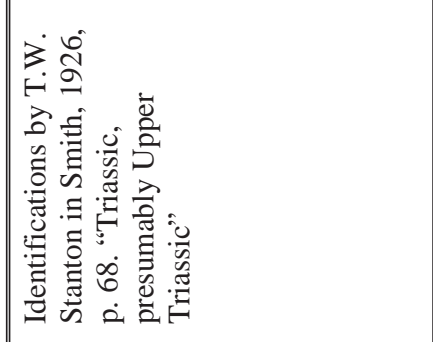 & 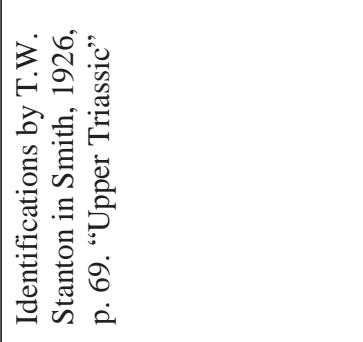 & 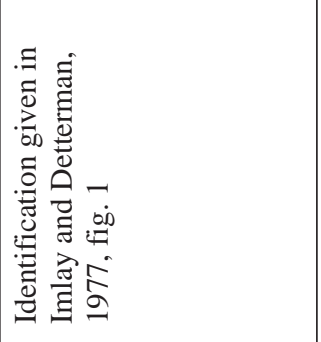 & 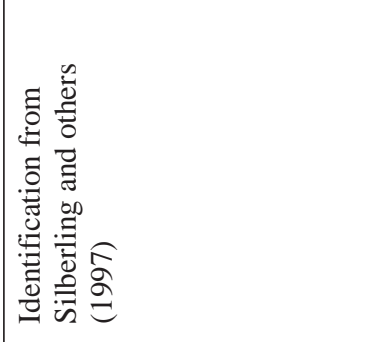 \\
\hline 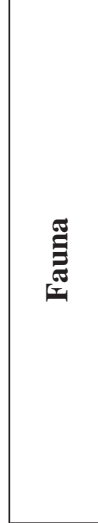 & 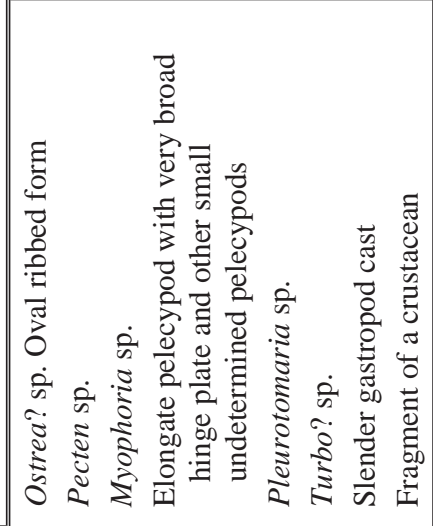 & 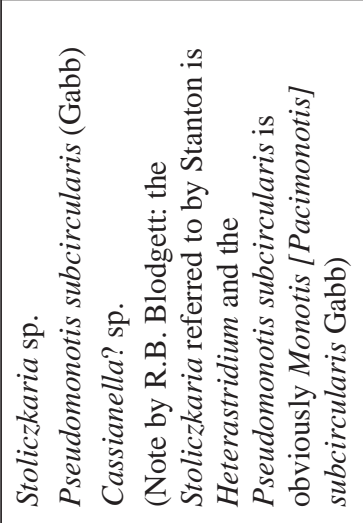 & 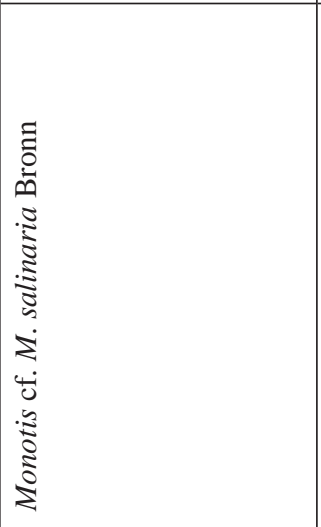 & 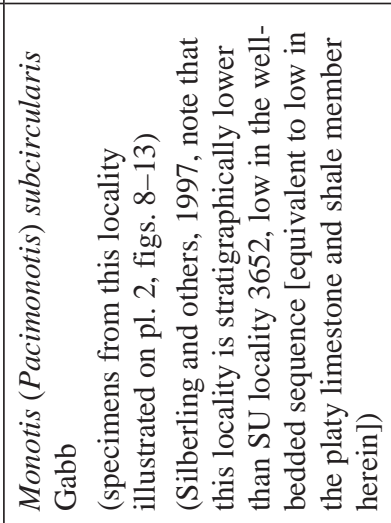 \\
\hline 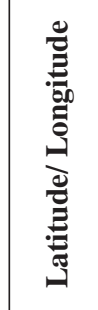 & 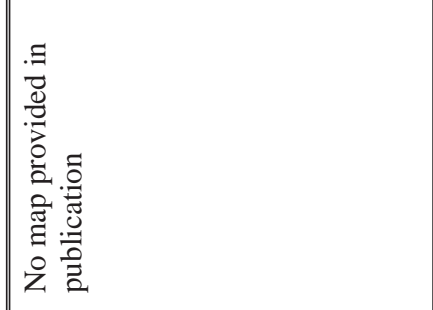 & 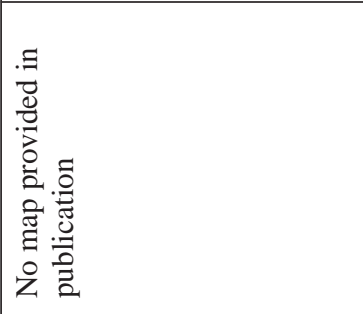 & 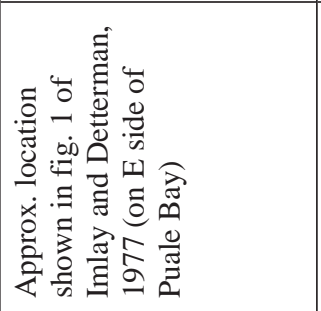 & 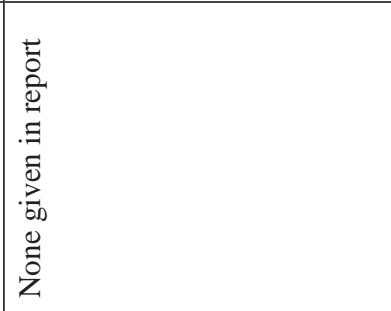 \\
\hline 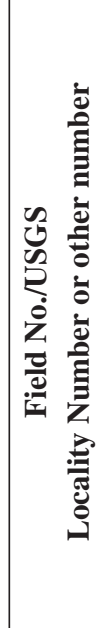 & 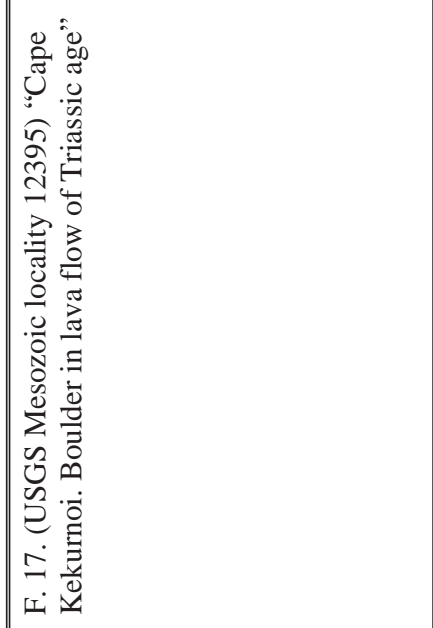 & 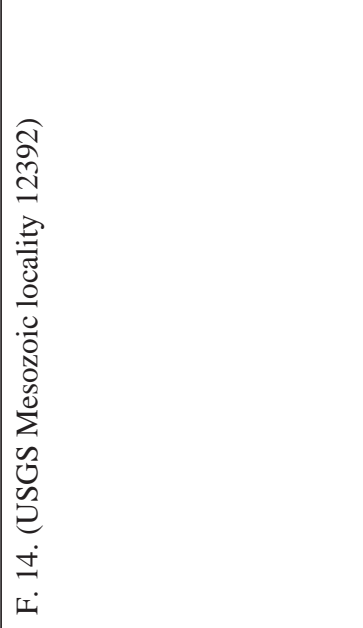 & 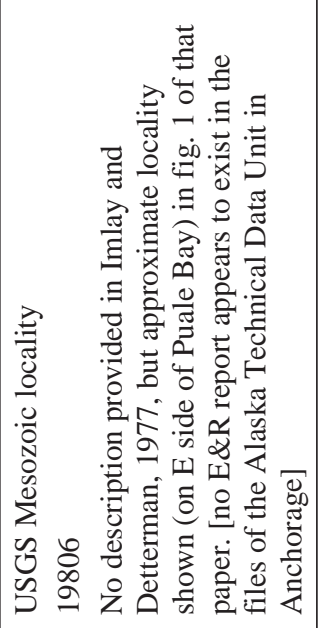 & 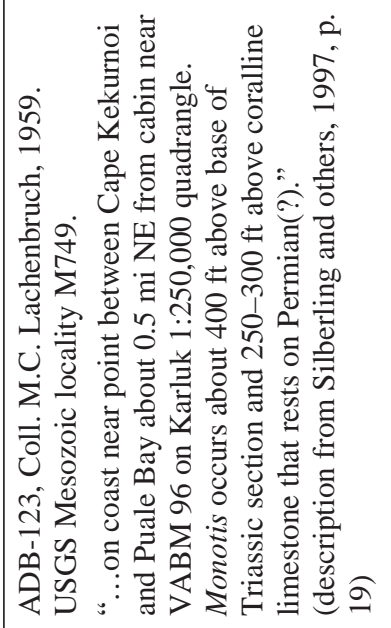 \\
\hline
\end{tabular}




\begin{tabular}{|c|c|c|c|c|c|}
\hline 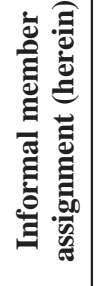 & 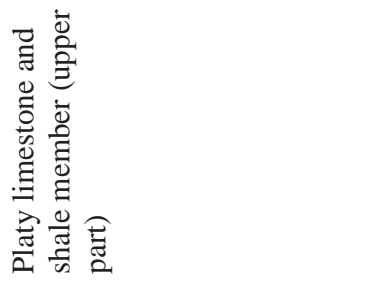 & 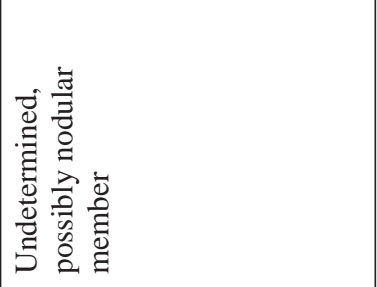 & 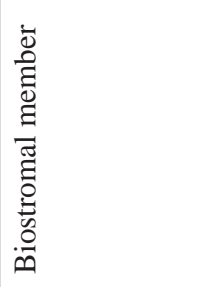 & 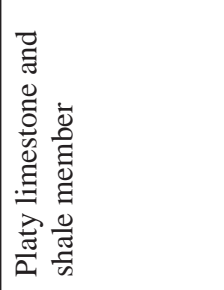 & 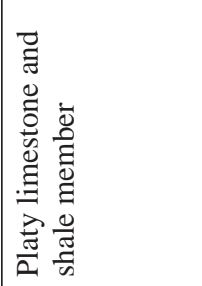 \\
\hline 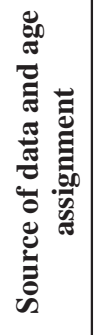 & 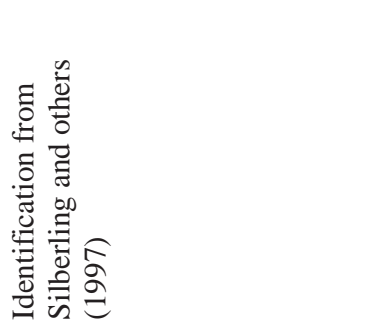 & 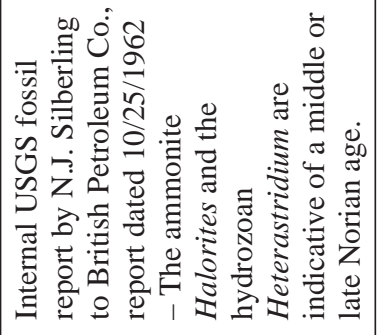 & 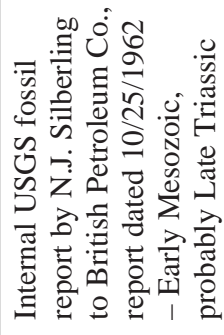 & 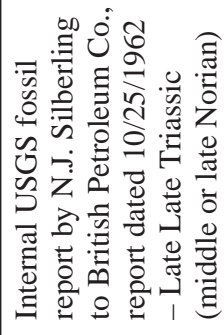 & 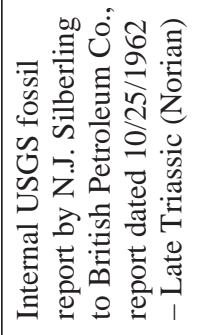 \\
\hline 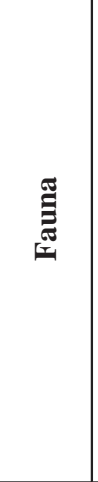 & 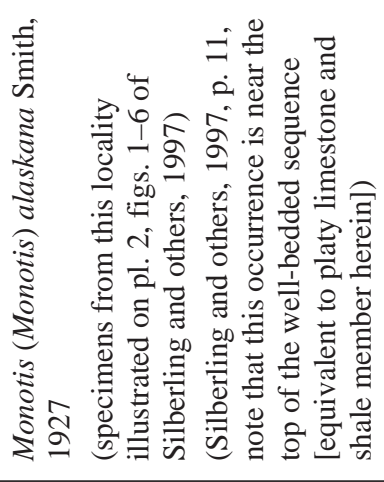 & 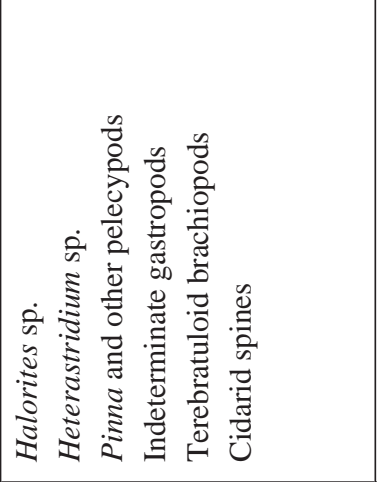 & 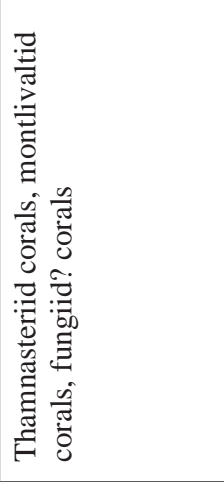 & 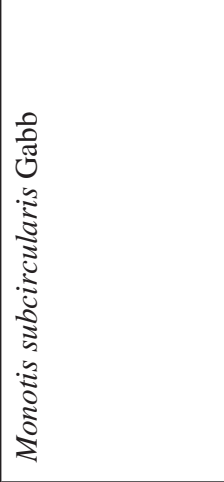 & 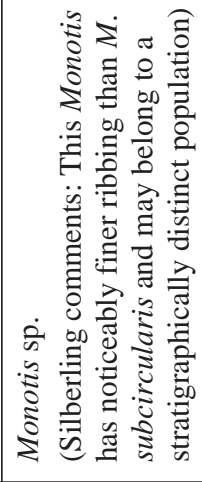 \\
\hline 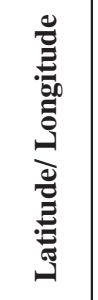 & 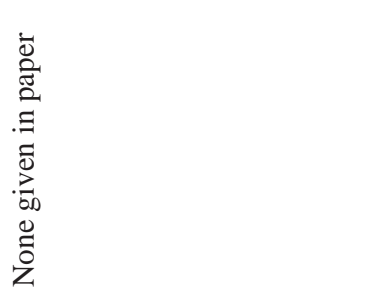 & 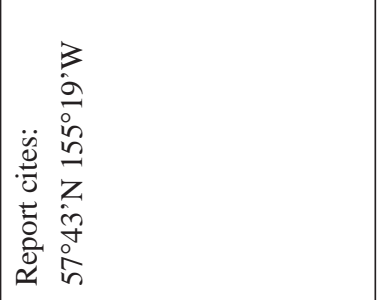 & 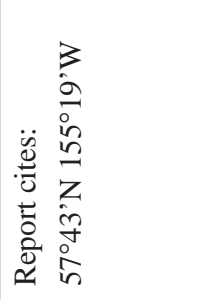 & 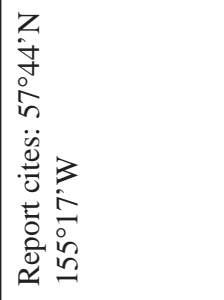 & 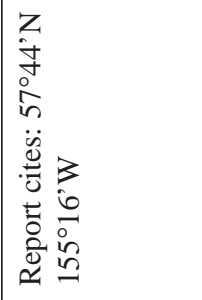 \\
\hline 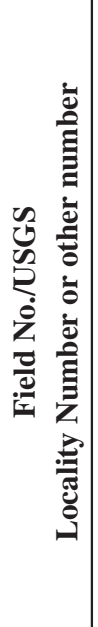 & 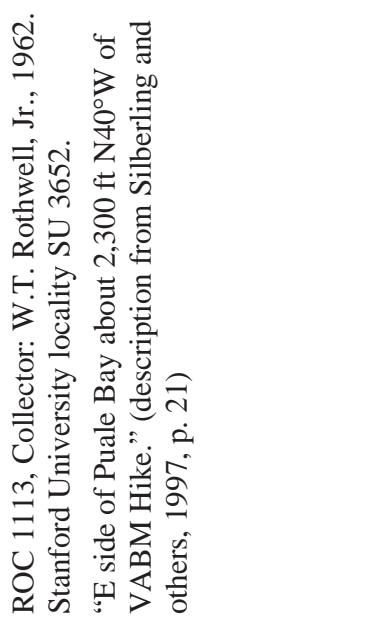 & 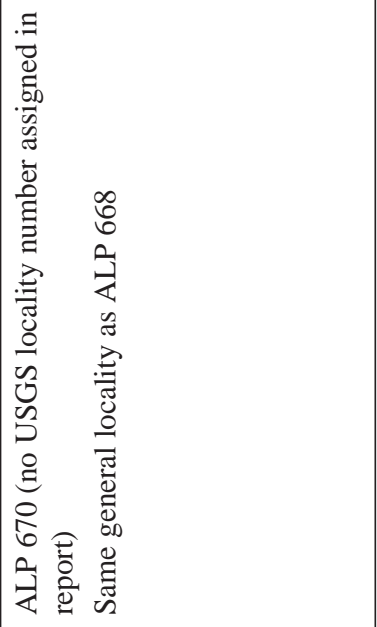 & 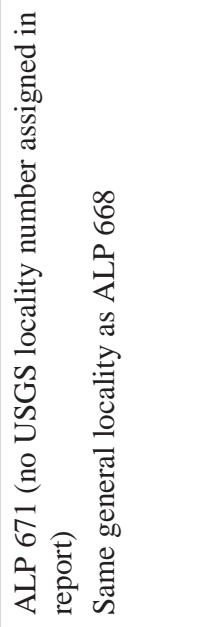 & 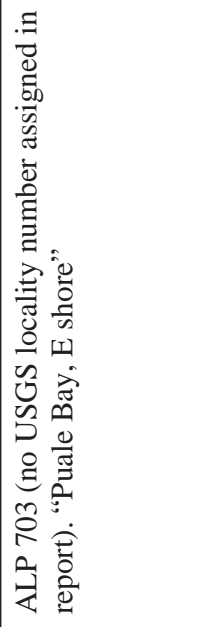 & 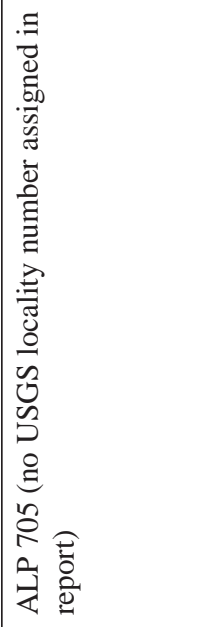 \\
\hline
\end{tabular}




\begin{tabular}{|c|c|c|}
\hline 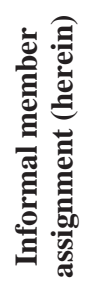 & 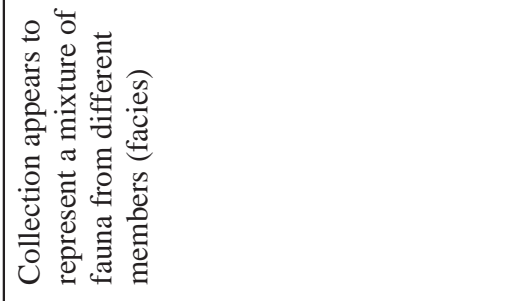 & 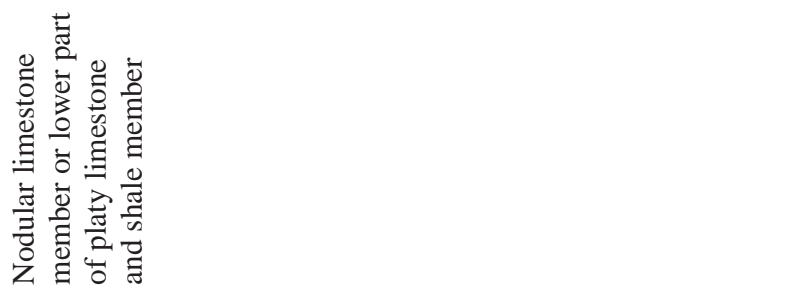 \\
\hline 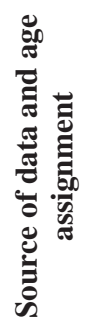 & 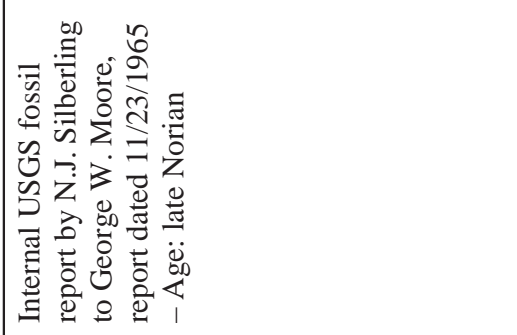 & 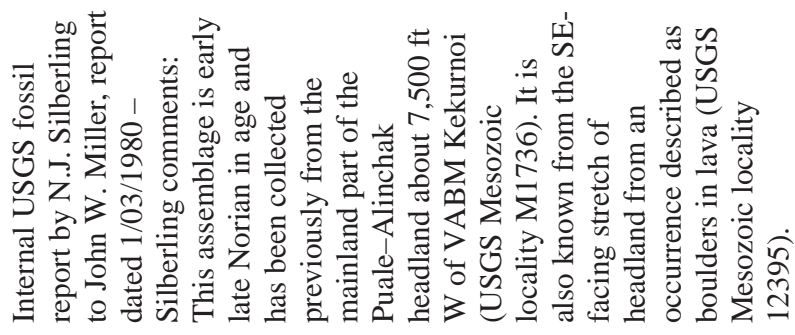 \\
\hline 党 & 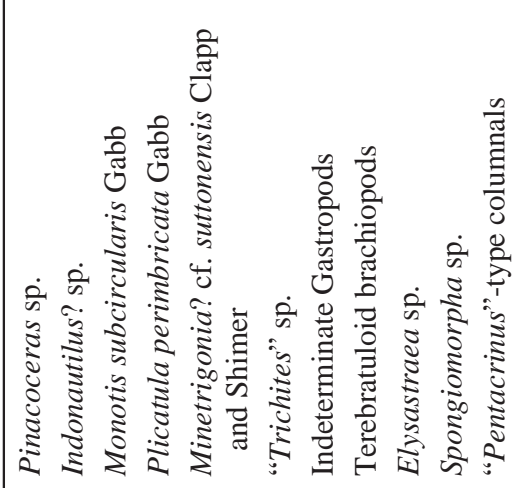 & 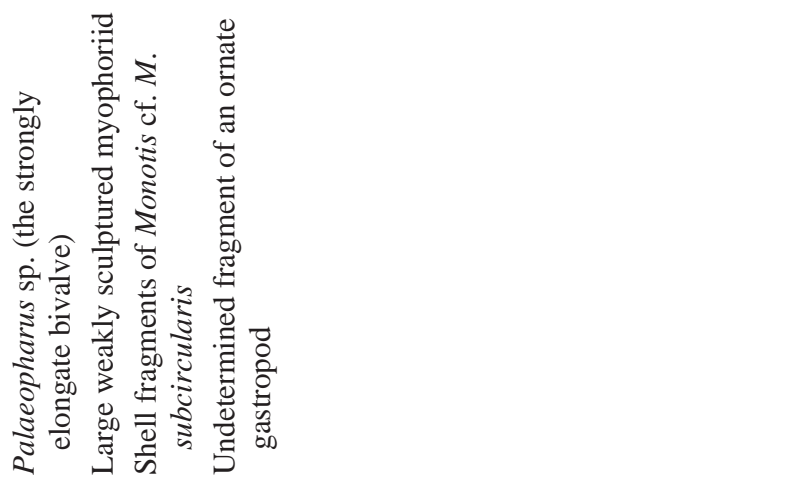 \\
\hline 兽 & 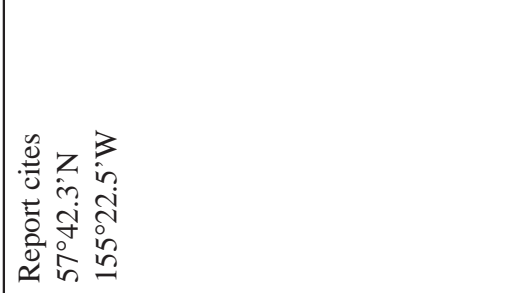 & 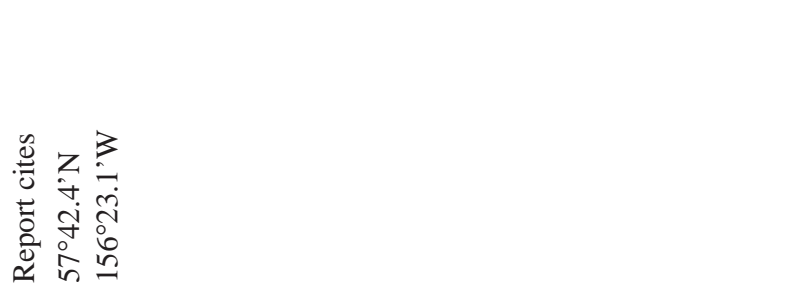 \\
\hline 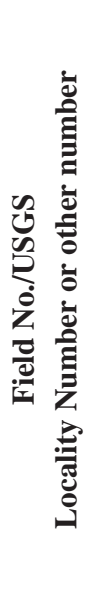 & 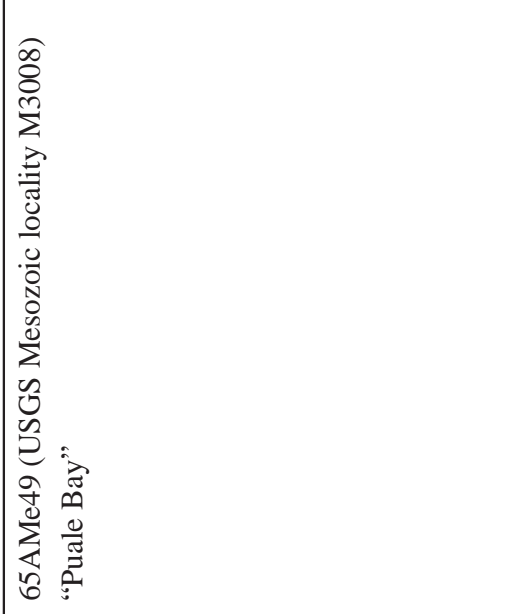 & 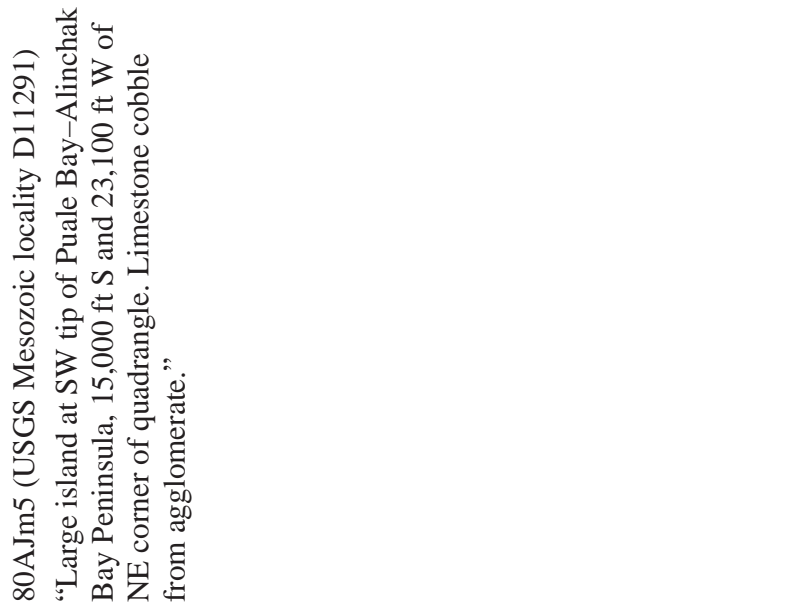 \\
\hline
\end{tabular}




\begin{tabular}{|c|c|c|c|c|c|c|}
\hline 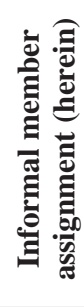 & 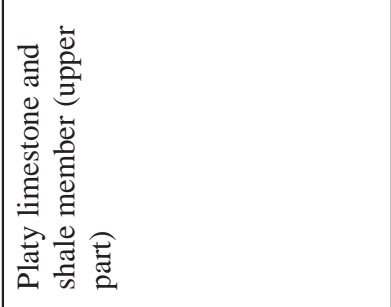 & 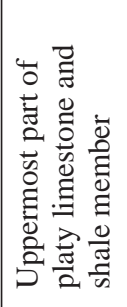 & 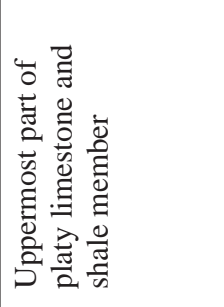 & & & 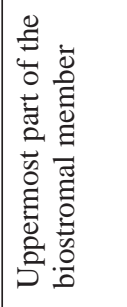 \\
\hline 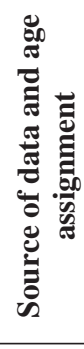 & 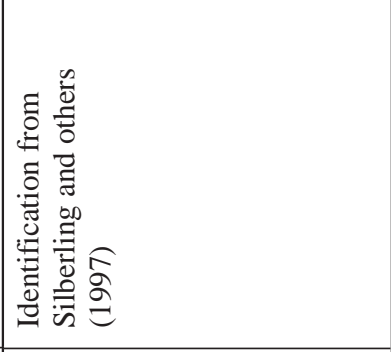 & 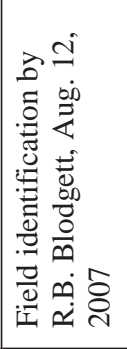 & 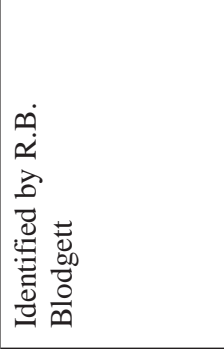 & & 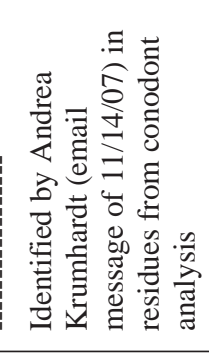 & 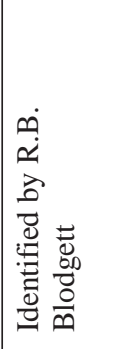 \\
\hline 莬 & 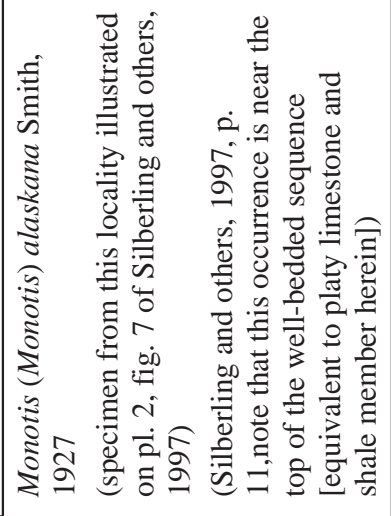 & 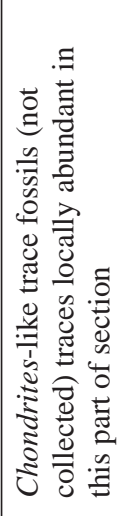 & 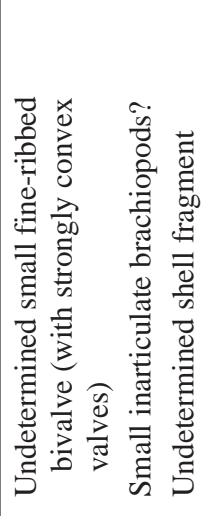 & 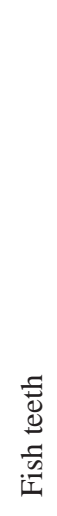 & & 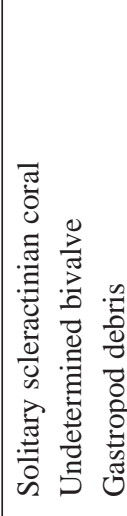 \\
\hline 营 & 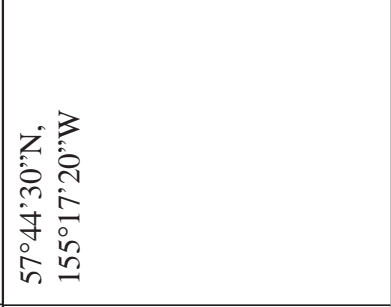 & 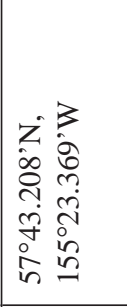 & 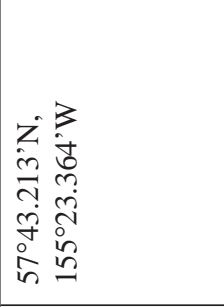 & & & 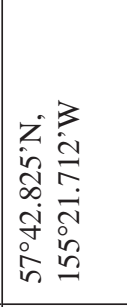 \\
\hline 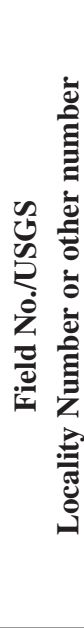 & 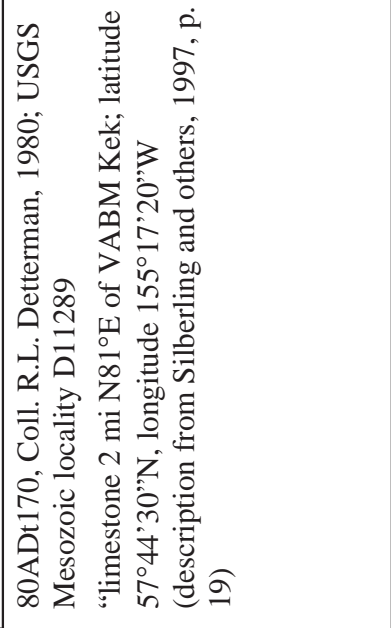 & 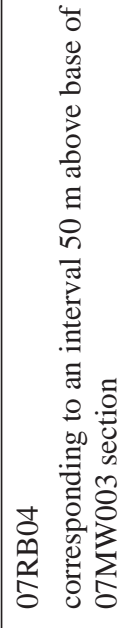 & 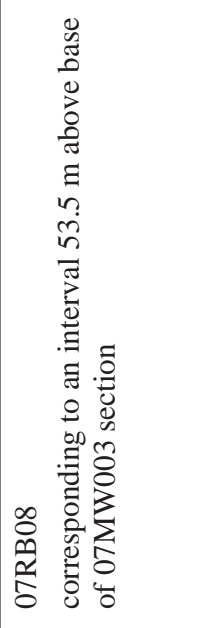 & & & 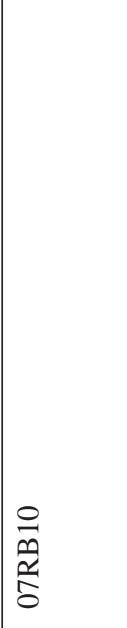 \\
\hline
\end{tabular}




\begin{tabular}{|c|c|c|c|c|}
\hline 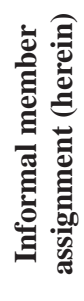 & 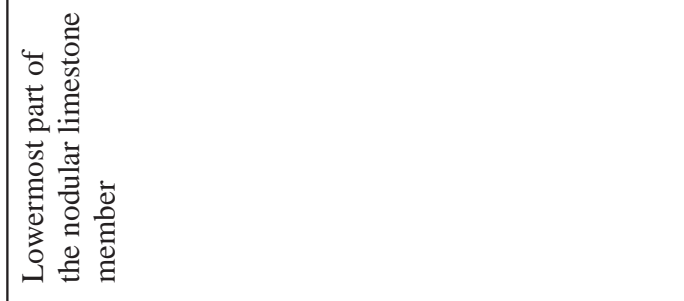 & & & 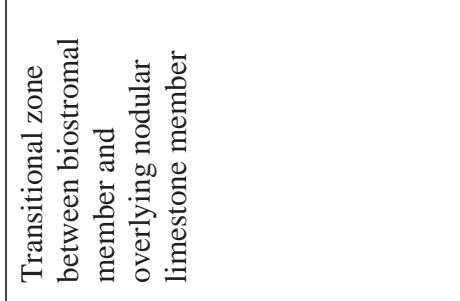 \\
\hline 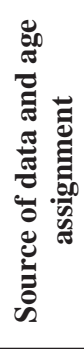 & 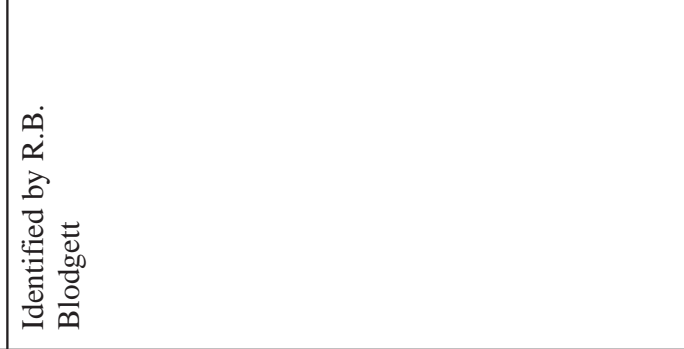 & & 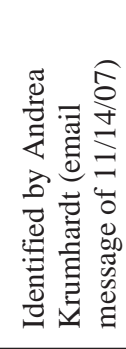 & 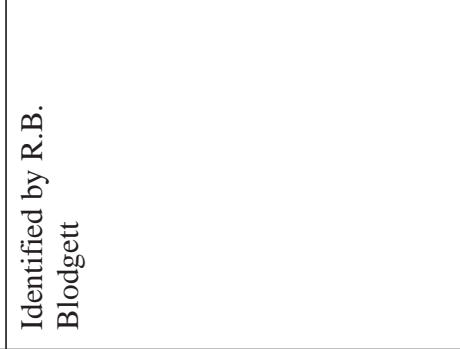 \\
\hline 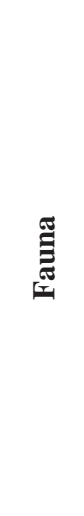 & 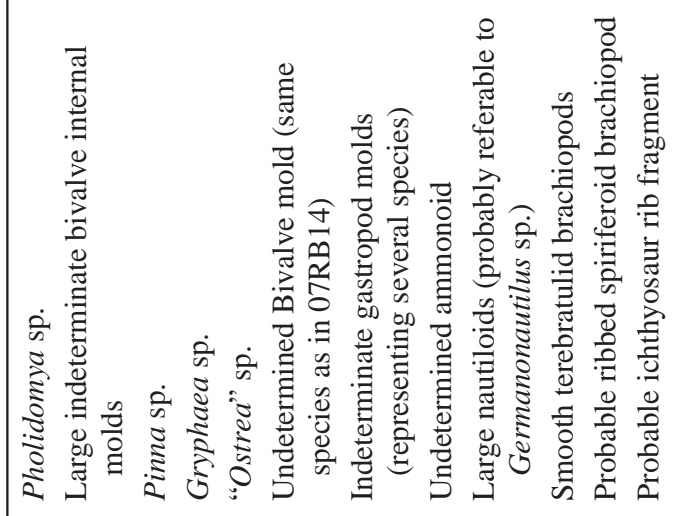 & 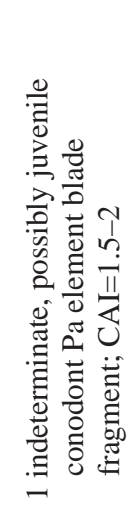 & & 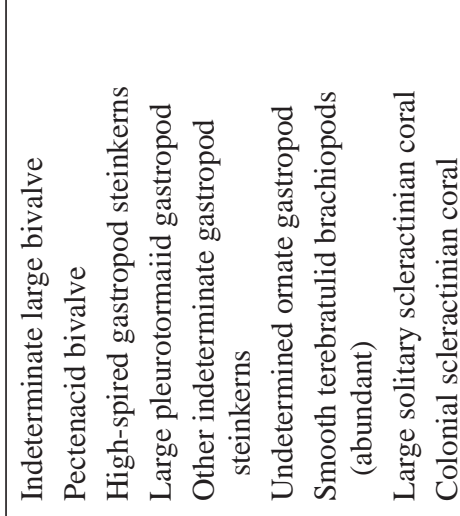 \\
\hline 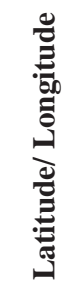 & 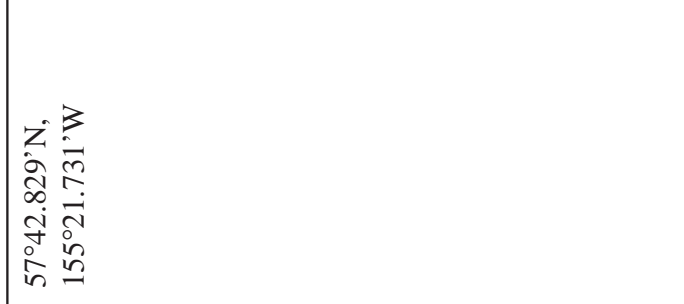 & & & 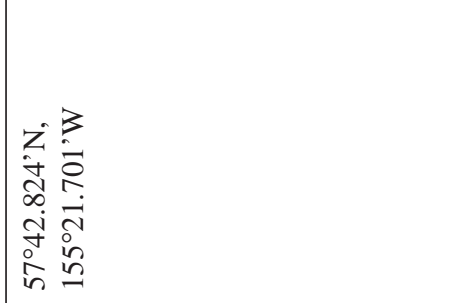 \\
\hline 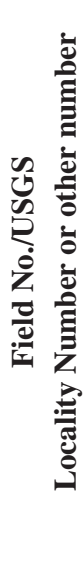 & $\begin{array}{l}\overrightarrow{\vec{p}} \\
\underline{\underline{A}} \\
\underline{\hat{\sigma}}\end{array}$ & & & 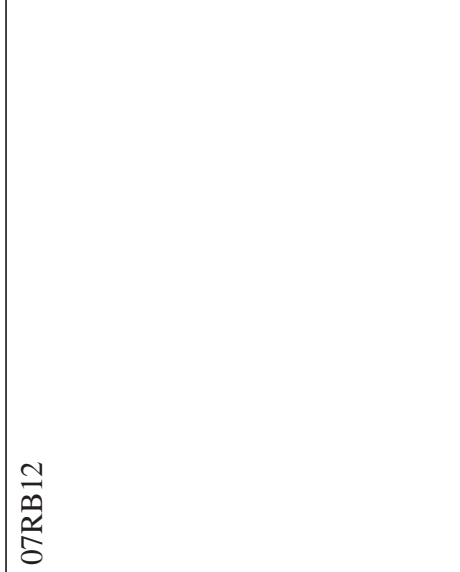 \\
\hline
\end{tabular}




\begin{tabular}{|c|c|c|}
\hline 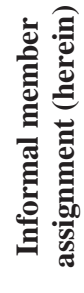 & 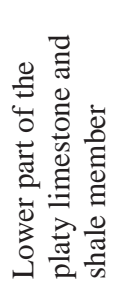 & 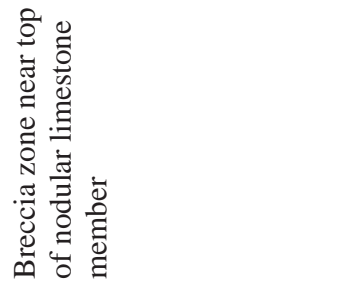 \\
\hline 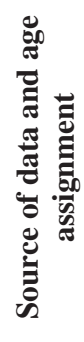 & 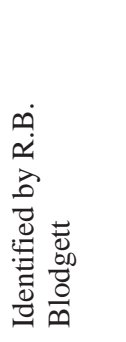 & 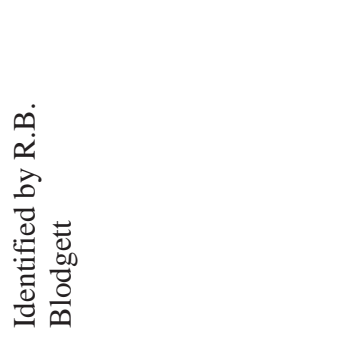 \\
\hline 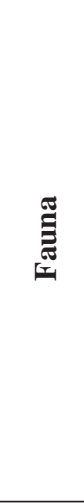 & 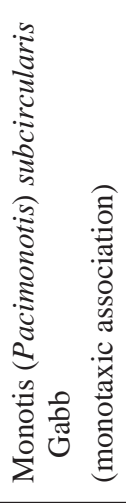 & 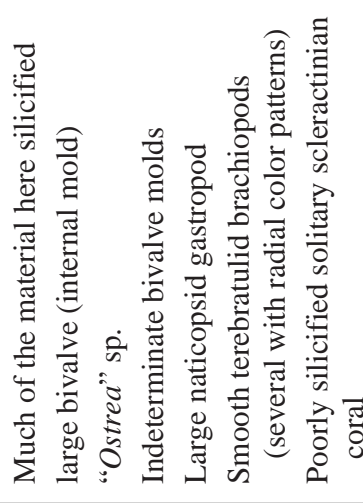 \\
\hline 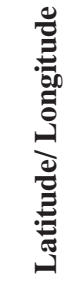 & 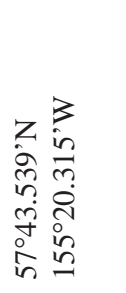 & 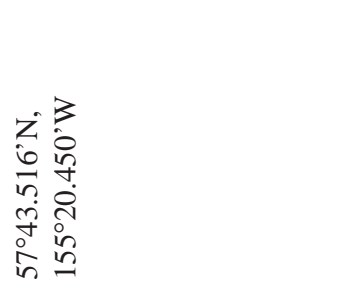 \\
\hline 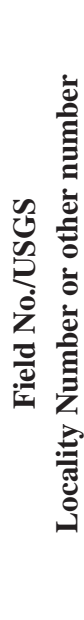 & 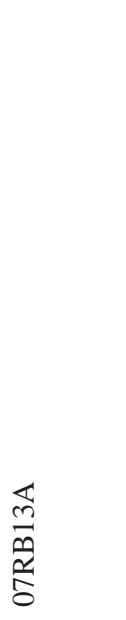 & 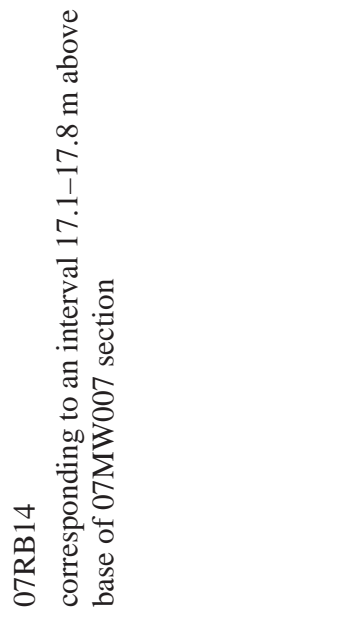 \\
\hline
\end{tabular}

